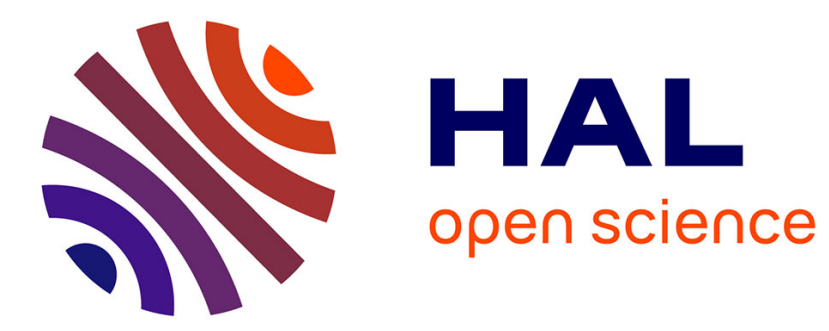

\title{
Fewer courts, less justice? Evidence from the 2008 French reform of labor courts
}

Romain Espinosa, Claudine Desrieux, Hengrui Wan

\section{To cite this version:}

Romain Espinosa, Claudine Desrieux, Hengrui Wan. Fewer courts, less justice? Evidence from the 2008 French reform of labor courts. European Journal of Law and Economics, 2017, 43 (2), pp.195-237. $10.1007 /$ s10657-015-9507-y . halshs-01634211

\section{HAL Id: halshs-01634211 https://shs.hal.science/halshs-01634211}

Submitted on 14 Nov 2017

HAL is a multi-disciplinary open access archive for the deposit and dissemination of scientific research documents, whether they are published or not. The documents may come from teaching and research institutions in France or abroad, or from public or private research centers.
L'archive ouverte pluridisciplinaire HAL, est destinée au dépôt et à la diffusion de documents scientifiques de niveau recherche, publiés ou non, émanant des établissements d'enseignement et de recherche français ou étrangers, des laboratoires publics ou privés. 


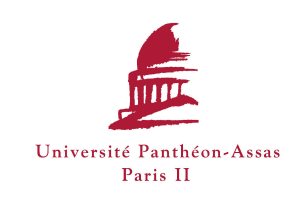

\title{
Fewer Courts, Less Justice? Evidence from the 2008 French Reform of Labor Courts
}

\author{
Romain Espinosa*, Claudine Desrieux ${ }^{\dagger}$ And Hengrui Wan ${ }^{\ddagger}$
}

July 2015

\footnotetext{
${ }^{*}$ CRED - Université de Paris II - 12 place du Panthéon, 75005 PARIS. Phone: + 33 (0)1 44415660. Email : romain.espinosa@u-paris2.fr

${ }^{\dagger}$ CRED - Université de Paris II - 12 place du Panthéon, 75005 PARIS. Phone: + 33 (0)1 44418991. Email : claudine.desrieux@u-paris2.fr

$\ddagger$ This article was realized when $\mathrm{H}$. Wan (student at ENSAE) made his internship at CRED research center.
} 


\section{Contents}

1 Introduction $\quad 1$

2 Literature Review $\quad 2$

3 The Institutional Setting $\quad 3$

3.1 French Labor Courts . . . . . . . . . . . . . . . . . . . . 3

3.2 Overview of the 2008 Reform . . . . . . . . . . . . . . . . 4

4 Stylized Facts $\quad \mathbf{5}$

4.1 Presentation of the Databases . . . . . . . . . . . . . . . 5

4.2 Evolution of the Number of New Claims and of Case Duration Over Time $\quad$. 7

5 Empirical Studies $\quad 9$

5.1 Investigation on Courts' Removal Decisions . . . . . . . . . . . . . . . . . 9

5.1.1 Empirical Strategies . . . . . . . . . . . . . . . . . . . 9

5.1 .2 Main Results . . . . . . . . . . . . . . . . . . 12

5.2 Reform's Impact on Caseload and Case Duration . . . . . . . . . . . . . . . 14

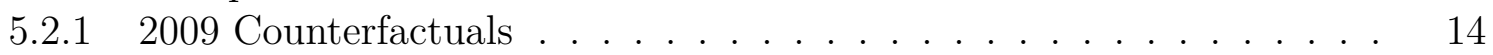

5.2.2 Econometrics . . . . . . . . . . . . . . . 15

6 Concluding Remarks $\quad 23$

A Appendix 1: Maps of Judicial System 30

B Appendix 2: Tables and Figures $\quad 32$

C Appendix 3: Marginal effects

D Appendix 4: Marginal Effects at the National Level 38

E Appendix 5: Graphs of marginal effects $\quad 40$ 


\begin{abstract}
The need to provide a high-quality justice at reasonable cost represents a current challenge for many public authorities. Many reform projects propose to remove some courts in order to rationalize the judiciary. This paper explores the 2008 French reform of labor courts (removing $20 \%$ of the courts) to empirically investigate the determinants of the removal decision, and its consequences on caseload and case duration in the remaining courts. This represents -to our knowledge- the first attempt to evaluate the impacts of courts' removal. Using panel data, our empirical strategy is based on probit estimations, counterfactuals, as well as 3SLS estimations. Our results show that the reform targeted small and concentrated courts. At the aggregated national level, it appears that duration did not increase, but the demand for litigation decreased. Locally, we find that courts were affected in different ways according to the relative burden they took on.
\end{abstract}

JEL Codes: K40; K41; K31

Keywords: judiciary reform; courts' removal; judicial map; case duration; caseload

\title{
1 Introduction
}

With the growing constraint on public finance, the question of judiciary organization has become a major concern all over the world, and especially in Europe. In 2011, the ENCJ (European Network of Councils for the Judiciary) adopted the Vilnius Declaration which lists a set of recommendations to respond to the current challenges and opportunities European judiciaries face due to the new economic landscape. The rationalization and re-organization of courts is motivated by the need to provide high-quality justice, and to make a more efficient use of the available resources. In the light of these concerns, France reformed in 2008 its judiciary by reorganizing and reducing the number of courts. The reform removed $20 \%$ of the labor courts. In this paper, we explore the determinants and the consequences of this reduction in the number of labor courts.

More precisely, we intend to investigate $(i)$ the criteria that governed labor courts' removal, and $(i i)$ the consequences of this reform on caseload and case duration. To do so, we build a cross-section and a panel databases. We collected information from the French Ministry of Justice on caseload and case duration in all French labor courts between 2004 and 2012, i.e. four years before and after the reform. We completed our databases by collecting information on the geographical distance between courts as well as on some macroeconomic indicators (such as unemployment rates or GDP levels) and the population in those areas. We also gathered information on the political representation of each area (i.e. the political affiliation of the Parliament's local representatives).

We run a probit estimation to figure out which factors drove the decisions of courts' removal. Results show that the reform targeted small and isolated courts in high-unemployment areas. Political considerations do not appear as significant. To understand the impact of the reform on caseload and case duration, we first propose a counterfactual analysis. This approach fails at detecting a contraction of the demand for litigation after the reform. Second, we run 3SLS estimations. At the national aggregated level, we detect a small contraction in demand for litigation. This contraction has been particularly strong in courts taking on a large burden from removed courts. Regarding the delays, our investigation does not find any significant increase at the national level. We show however that courts receiving a large burden might have suffered from increased delays, especially since 2011. 
The originality of our work is to propose an evaluation of a recent reform reducing the number of courts. Our investigation is, to the best of our knowledge, the first attempt to assess the impacts of courts' removal on the judiciary. This may sound surprising, as many European countries (as Denmark, the Netherlands, Norway, Ireland, Portugal and Greece) have progressively implemented reforms including such removals. In some other countries, like Belgium or Italy, the revision of the judicial map is considered necessary, but no consensus on specific measures has been reached so far (ENCJ [2012]).

The paper is organized as follows: section 2 relates our paper to the previous economic literature. Section 3 presents the institutional context of the 2008 French reform of labor courts, and section 4 describes some stylized facts. Section 5 contains the empirical analysis of the determinants and consequences of courts' removal. Section 6 concludes and discusses our results.

\section{Literature Review}

The contribution of legal institutions to wealth creation and economic growth has drawn a lot of attention in the economic literature. From the early works of Smith [1762] or Montesquieu [1748] to more recent researches (Posner [1998], La Porta, Lopez-de Silanes, Shleifer, and Vishny [1998], Djankov, La Porta, López-de Silanes, and Shleifer [2003], Botero, Porta, and López-de Silanes [2004] or Acemoglu and Johnson [2005]), the role of the legal framework in the economic activity has kept on being emphasized.

However, law can foster trade, investment and ultimately economic growth only if it is enforced in good conditions. In the light of these considerations, a growing attention has been devoted to the organization of the judiciary over the past decades. Without being exhaustive, topics such as the number of judges (Posner [2000], Beenstock and Haitovsky [2004], Dimitrova-Grajzl, Grajzl, Sustersic, and Zajc [2012a], Mitsopoulos and Pelagidis [2007]), judges' monetary incentives (Boylan [2004], Yoon [2006], Choi, Gulati, and Posner [2009a], Deyneli [2012], Garoupa, Dalla Pellegrina, and Suardi [2015]), training (Chemin [2009]) or

appointment (Maskin and Tirole [2004], Choi, Gulati, and Posner [2010], Lim [2013]) have been explored. Our work departs from these papers to the extent that it is primarily interested with courts' organization rather than with judicial behavior.

More precisely, our paper deals with the determinants and the effects of a reduction in the number of courts. The question of the optimal number of courts has drawn some attention in the legal literature (Gomes [2007], Mak [2008], Van Djik and Horatius [2013]), and has raised many concerns in public debates (World Bank [2011], Sénat [2012], ENCJ [2012]). Yet, the economic literature has devoted little attention to this problem. Existing contributions to this topic are mainly theoretical. Chappe [2012] models how the demand for litigation evolves when courts are congested. She stresses that delay reduction efforts (such as greater court capacity) may be offset by a resulting increase in the demand for litigation, when litigants integrate congestion into their utility function. Chappe and Obidzinski [2014] also investigate the question of the optimal number of courts. They show that decreasing the number of courts has non-conclusive effects on the demand for litigation. Depending on the defendant's transport costs, diminishing the number of courts may induce more care (fewer accidents) and fewer suits, so that congestion may decrease. Nevertheless, this paper does not provide any empirical evidence supporting this proposition. More broadly, no paper - to our knowledge- has proposed an empirical investigation of a reform reducing the number of 
courts.

To evaluate the impacts of such a reform, we focus on the number of new cases brought to courts and on the average duration of claims. Judicial performance is multi-dimensional (Djankov et al. [2003], Cross and Lindquist [2009], Choi, Gulati, and Posner [2009b, 2011, 2012]), but our focus is limited to these two indicators. Prior to its implementation, opponents to the reform argued that reducing the number of courts would make access to justice more difficult, and would increase court congestion. They emphasized that judicial delays are a strong concern in France, especially in labor courts (Marshall [2013], Lacabarats [2014]). ${ }^{1}$ As a consequence, our goal is not to propose a full evaluation of the reform, but to analyze whether the fears of the opponents regarding delays and demand for litigation were properly grounded.

Last, our paper is also related to the large literature on judicial reforms. ${ }^{2}$ Many reports from the World Bank or other international organizations (Buscaglia, Dakolias, and Ratliff [1995], Buscaglia [2001], Dakolias [1996, 1999], Dakolias and Said [1999], World Bank [2012], European Commission [2014], Doing Business [2014], IMF [2014]) encourage judicial reforms to promote an independent, trustful and credible justice. Other organizations published reports to share experiences on practices in the judicial sector (Webber [2007], CEPEJ [2014a], OECD [2013]). The common idea shared by all these contributions is that a well-organized, credible and independent judicial system has positive consequences on economic outcomes. Following this idea, Botero, Porta, López-de Silanes, Shleifer, and Volokh [2003] review evidence on judicial reforms and their impacts on economic performances. Chemin [2012] analyzes the impact of a reform aiming at reducing delays on firms' behavior. However, none of these contributions provides for empirical evidence of the determinants and consequences of the reduction in the number of courts, while many public decision-makers are discussing such reforms.

\section{The Institutional Setting}

\subsection{French Labor Courts}

Created by Napoléon in 1806, French labor courts ( Conseils de Prud'hommes") are first-level tribunals ${ }^{3}$, dealing with individual disputes affecting labor relationships in the private sector (validity of employment contracts, nullification of a dismissal, monetary compensations, level of severance payments, ...). Most of the cases are however brought by fired workers challenging their dismissals. ${ }^{4}$ These courts only deal with individual disputes, since disputes

\footnotetext{
${ }^{1}$ In 2013, France was convicted 66 times for judicial dysfunctions, including 51 cases relative to denial of justice in labor courts, caused by excessive delays (Lacabarats [2014]). However, concerns about excessive delays are not specific to France. The European Commission for the Efficiency of Justice (CEPEJ), created by the Committee of Ministers of the Council of Europe in September 2002, was primarily set up to propose concrete solutions to current problems face by judiciaries, notably to reduce congestion in the European Court of Human Rights (CEPEJ [2014b]).

${ }^{2}$ Another strand of literature has explored reforms of legal services, such as legal education and the structure of law firms (Ribstein [1998], Stephen [2002, 2013], Garoupa [2014]). These works deal with important reforms relative to judicial staff, but not with the organization of the judiciary per se.

${ }^{3}$ Appeals are brought before the "Cour d'Appel" ("Chambre sociale"), and appeals against decisions of the "cour d'appel" are lodged in the "Cour de cassation" ("Chambre sociale").

${ }^{4}$ According to the French Ministry of Justice, 8 out of 10 cases in labor courts come from fired workers challenging their dismissals. Other cases are mainly about unpaid wages or unpaid compensations (De Mail-
} 
affecting collective labor relationships are dealt with by ordinary civil courts ("Tribunal de grande instance"). There exist today 210 courts spread all over the territory. Each court is divided into 5 sections by activity (agriculture, commerce, industry, executives and diverse activities). Judges of labor courts are not professional judges but elected representatives of employees and employers. These lay judges (also called "councillors") are elected on a parity basis: there is an absolute equality between lay judges representing employees and lay judges representing employers.

When a claim is brought to a labor court, it has to go first through the conciliation board ("bureau de conciliation"). If parties fail to settle at this stage, the plaintiff may either drop the case or go to the "bureau de jugement" (ruling panel), comprising two employer lay-judges and two employee lay-judges. In case of split votes within the ruling panel, a professional judge is asked to complete the jurisdiction in order to settle votes. Such an intervention is called "départage". In 2012, 146,192 new claims were brought to labor courts, and 158,391 claims were terminated. More precisely about termination, 67,567 were settled or dropped, 74,213 had a decision from "bureau de jugement" and a professional judge made the decision for 16,611 of them.

Labor courts in France represent a fair share of the total demand for litigation. As previously mentioned, 146,192 new cases were brought to the 210 labor courts in 2012. By comparison, in the same time, 196,630 new cases were opened in the 149 commercial courts and 674,760 new cases were brought to the 303 standard civil courts ("tribunaux d'instance"). Labor courts suffer however from great delays. Indeed, cases brought to labor courts need about 11.9 months to be terminated, while civil courts and commercial courts decide in half the time (respectively 5.4 and 5.8 months on average).$^{5}$

\subsection{Overview of the 2008 Reform}

A reform project to reduce the number of courts in France was discussed in 2008. The reasons exposed by the government to support this reform were $(i)$ the inadequacy between demographical evolution and the allocation of courts in the country, and ( $i i)$ the need to rationalize the management of courts. ${ }^{6}$ The total cost of this reform is today evaluated to $413 \mathrm{M} €$, and the savings on administrative expenditures are estimated to $9.1 \mathrm{M} €$ per year (Cour des comptes [2015]). ${ }^{7}$ A strong motivation for the reform was to remove courts with low activity levels, and to give more means to courts dealing with a larger number of claims. Before the reform, there were 1,206 courts in France, among which 271 were first-level labor courts. Strong inequalities of access could be observed: some départements ${ }^{8}$ had 14 labor courts, while some others had only one (Sénat [2012]). The reform was enacted by decree

\footnotetext{
lard Taillefer and Timbart [2009]).

${ }^{5}$ Statistics come from both the Ministry of Justice (www.justice.gouv.fr/statistiques.html) and a report ordered by the Minister of Justice in 2014 (Lacabarats [2014]).

${ }^{6}$ The last general reform regarding the number of courts in France dated back to 1958. Another smaller reform targeting only labor courts was implemented in 1992: 11 labor courts were removed.

${ }^{7}$ These figures come from the institution in charge of evaluating the public organizations and public services in France (Cour des Comptes). They are relative to the whole reform. Let us recall that this reform concerned not only labor courts but also civil and commercial courts. A total of 341 courts were removed, among which 62 were labor courts.

${ }^{8}$ Départements are French administrative subdivisions of the territory. Metropolitan France is made up of 95 Départements.
} 
$\mathrm{n}^{\mathrm{o}} 2008-514$ of May $29^{\text {th }}, 2008$, and removed 62 labor courts, i.e. more than $20 \%$ of the 271 former labor courts. One court was created, so that the total number of labor courts became 210 after the reform. The judicial map was redrawn: areas with removed courts were affected to other labor courts. This reform was effective on December $3^{r d}, 2008 .^{9}$ Two main criteria were announced as determining the choice of removed courts: first, public authorities wanted to maintain at least one labor court per "département" 10 , and second, to remove low-activity courts (i.e. fewer than 500 new cases each year). Figures 3 and 4 in Appendix 1 show the judicial map of French labor courts before and after the reform.

While discussing the reform, policy-makers were mainly concerned by two aspects. First, some opponents to the reform argued that potential litigants would be prevented to go to court because of the increased distance to the new local court (Sénat [2012]). Second, some concerns were raised about the potential congestion of new courts, which would increase (already high) case duration, and would, in turn, prevent even more litigants to go to court. ${ }^{11}$ Regarding the second aspect, the government answered that the reform would have little impact on case duration, arguing that judges from removed courts would be transferred to courts which would take on the geographical competence of the removed courts. In other words, the number of judges remains constant, and, therefore, case duration should not increase after the reform in receiving courts compared to the courts which were not affected by the reform. Last, some opponents to the reform criticized the choice of the removed courts. They claimed that this choice was made on political considerations rather than efficiency criteria. ${ }^{12}$

In the following section, we present the data that allow us to see whether all these fears were properly grounded or not.

\section{Stylized Facts}

\subsection{Presentation of the Databases}

Our objectives are twofold: (i) finding out the determinants of courts' removal, and (ii) assessing the impact of the reform on the caseload and the average case duration in the remaining labor courts. Two distinct databases are used to achieve these objectives. First, we establish a cross-section dataset to figure out the characteristics of removed courts. Second, we build a panel database to evaluate the effects of the reform: we consider four years before and four years after the reform.

Since the government's decision on courts' removal was made in 2008, we first focus on 2007 data to build the cross-section database for the court removal analysis. Here we consider

\footnotetext{
${ }^{9}$ Judges of removed labor courts were reallocated to other courts. Some 114 civil servants were working in removed labor courts: most of them have been reallocated to other jurisdictions, and 26 positions have been removed between 2008 and 2010 (Sénat [2012]).

${ }^{10}$ The exact criterion was to keep one labor court per "département", and one on the geographical area of each civil court. These two geographical areas are more or less the same.

${ }^{11}$ Illustrations of those fears were expressed in many newspapers, as in Le Monde, http : //www.lemonde.fr/societe/article/2012/07/13/la-reforme-de-la-carte-judiciaire-une-occasionmanquee - selon - la - commission - des - lois - du - senat_1733397_3224.html (Last Access: January 2015).

${ }^{12}$ Source: http ://rue89.nouvelobs.com/2008/08/07/reforme - de - la - carte - judiciaire - dati - a bien - dote - ses - amis (Last Access: January 2015)
} 
two dimensions: variables representing courts' activity, and those accounting for their environment. To collect information about labor courts' activity, we use data from the French Ministry of Justice. ${ }^{13}$ As explained above, we restrict our attention to two variables: the average number of new cases received between 2004 and 2007, and the average case duration. At the same time, we complete this database with some other data which account for the courts' environmental features, and which may influence decision-makers. First, we compute the distance between each court and its nearest court within the department. The rationale consists in exploring whether geographical concentration influenced courts' removal: courts may be more likely to be removed the closer the nearest court is, because litigants would not have to travel too far. ${ }^{14}$ Second, we take into account macroeconomic indicators: the unemployment rate in $2007^{15}$, the GDP per capita of $2005^{16}$ and the population density in 2009. ${ }^{17}$ These macroeconomic variables aim at controlling for the economic activity and the potential demand for litigation: higher unemployment rates, lower growth rate and higher population densities are likely to increase the demand for litigation, and, therefore, likely to affect choices to remove courts in such areas.

We also take into account the proportion of socialist deputies (Socialist Party, $P S$ ) in the city where the labor court is situated. ${ }^{18}$ Since the reform was conducted by a right-wing majority (UMP and UDI), one can believe that right-wing deputies may have been more efficient than left-wing deputies to preserve their labor court.

In order to assess the reform's impact on caseload and case duration, we construct a second dataset. ${ }^{19}$ This second dataset has a panel structure -it follows courts from 2004 to 2012-, and collects information similar to the cross-section dataset. We first consider two economic variables for each year between 2004 and 2012: the unemployment rate at the zone d'emploi's level and the GDP per capita at the région's level. ${ }^{20}$ Second, regarding the courts' activity, we take into account the average duration of terminated cases in months and the average annual caseload. These two variables are likely to influence each other. Case duration may determine the caseload, since longer delays increase litigation costs. In addition, more cases may lead to longer claim durations, as judges might be overloaded.

\footnotetext{
${ }^{13} \mathrm{http}: / /$ www.justice.gouv.fr/statistiques.html

${ }^{14}$ The distance is calculated with Google Maps, and corresponds to the number of kilometers litigants have to drive from their current court to the closest court.

${ }^{15}$ We take this rate at the Zone d'emploi (ZE) level. ZE are small subdivisions of the French territory used by the INSEE (the French Institute for Statistics). There are several ZE per département. We choose the unemployment rate at the ZE level because each labor court has a geographical competency in a given area that is close from the ZE.

${ }^{16}$ We take it at the "Département"'s level. This information was available for 2005 only.

${ }^{17}$ We take data from the 2009 census at the "Département"'s level.

${ }^{18}$ Data from the French National Assembly.

${ }^{19}$ Because of data availability, we exclude oversea regions from our analysis.

20 "Région" is another French administrative subdivision. Metropolitan France is currently made up of 22 "régions". GDP is not available at the "département" level so that we use the regional level.
} 


\subsection{Evolution of the Number of New Claims and of Case Duration Over Time}

As the above sections pointed out, policy-makers were particularly concerned by two dimensions: $(i)$ the geographical accessibility to labor courts, and ( $i i)$ case duration.

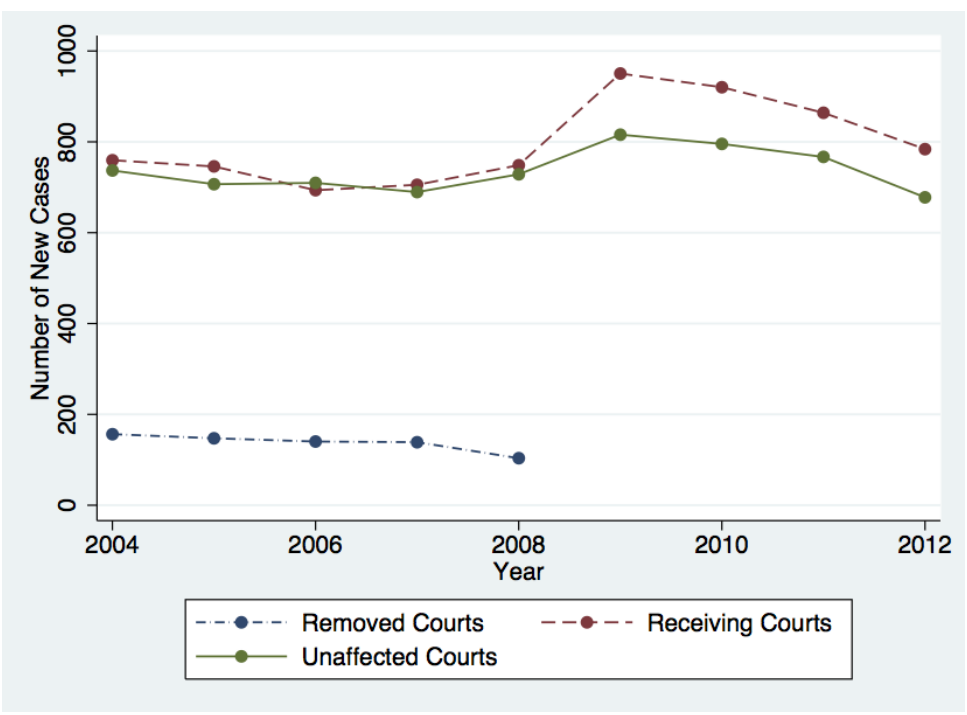

Figure 1: Number of new cases per type of labor court 2004-2012 (mean).

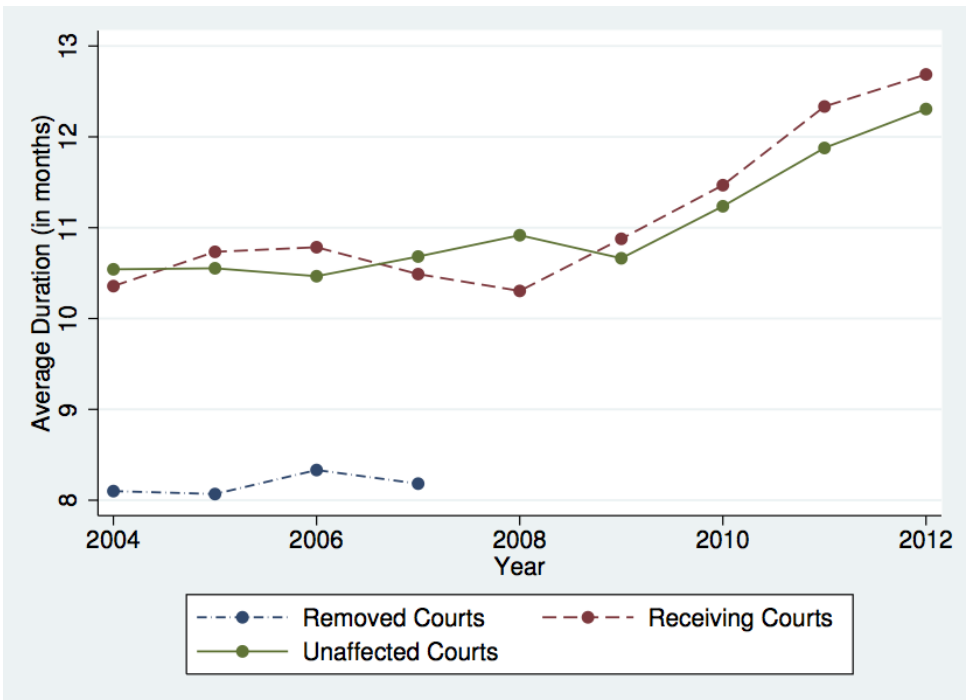

Figure 2: Evolution of the case duration per type of labor court 2004-2012 (mean).

New claims Figure 1 shows the average number of new claims brought to courts over the years. We distinguish between 3 groups:

- Courts that were not affected by the reform (unaffected courts): this group gathers all courts that were not removed, and whose geographical competency was unchanged by the reform; 
- Courts that were removed at the end of 2008 (removed courts);

- Courts that managed claims of removed courts after 2008 (courts receiving cases). The competency of these courts was extended after 2008 to cover the geographical areas of the removed courts. In the following, we refer to this third category as receiving courts.

The composition of these three groups was determined by the law (through decree $\mathrm{n}^{\circ} 2008$ 514 of May $\left.29^{t h}, 2008\right)$ as the legislator listed removed courts, and courts whose geographical competency was extended. All on-going and new claims from each removed court were reassigned to one (and only one) receiving court. ${ }^{21}$

Several trends can be observed from figure 1. First, one can see that, before the reform, removed courts received on average fewer cases than remaining courts (i.e. unaffected and receiving courts). This indicates that removed courts were selected for their particular low level of activity. Our calculations show that removed courts represented on average $5.8 \%$ of the demand for litigation between 2004 and 2007. Second, one can also remark that receiving courts and unaffected courts displayed similar trends. Prior to the reform, i.e. between 2004 and 2008, both types of courts received on average the same amount of cases, and the demand for litigation evolved in the same way.

Interestingly, the figure shows a gap between the two groups of remaining courts after the reform. Although this difference in 2009 is not significant $(p=0.537)$, this reflects the fact that receiving courts took on the geographical competences of the removed courts. ${ }^{22}$

Furthermore, we observe a peak in the number of cases in 2009. This increase is likely to result from the financial crisis. ${ }^{23}$ Indeed, economic recessions lead to higher job outflows and lower inflows. Two effects might follow. First, a higher rate of dismissal may de facto lead to more claims because the set of potential claims increases. Second, the contraction of the job market may lead to a greater job scarcity: workers are more willing to contest their dismissal because of the difficulty to find a new job.

Case Duration Figure 2 displays the evolution of the average case duration for each of the three groups of labor courts. ${ }^{24}$ We can first see that removed courts have had on average lower case duration than remaining courts. This is to link with Figure 1: removed courts had a low activity level, so that judges may have benefited from lower caseload and dealt more rapidly with the cases. Receiving and unaffected courts depict similar trends in case duration. One can also remark that all groups of courts have incurred an increase in duration since 2009. Because the number of claims increased in 2009 with the crisis, this probably created a congestion effect explaining the positive trend in claim duration. ${ }^{25}$

\footnotetext{
${ }^{21}$ In other words, litigants cannot choose the court to which they bring their cases. Litigants affected to a removed court are re-affected to a new court and are obliged to bring their claims to this specific designated court. This new reallocation was enacted by Decree $\mathrm{n}^{\mathrm{O}} 2008-514$ published on May 29th 2008 in the Official Journal of the French Republic. The Decree states that all cases are transferred as they stand and do not have to be reopened from the beginning.

${ }^{22}$ The p-value is associated with the two-group mean comparison test for 2009 .

${ }^{23}$ Source: http : //www.lemonde.fr/la - crise - financiere/article/2009/11/04/la - crise - dope - les recours - devant - les - prud - hommes_1262613_1101386.html

${ }^{24}$ Note that data for the duration of cases terminated in 2008 are not available for the removed courts.

${ }^{25}$ Note that the we do not observe such trends in other jurisdictions. Concerning the commercial courts, delays in 2009, 2010, 2011, and 2012 were 7.9, 7.4, 7.8, and 8.1 months on average at the national level. As far as civil courts are concerned, these delays were respectively 5.6, 5.9, 5.9 and 4.9 months. (These statistics come from the Ministry of Justice: www.justice.gouv.fr/statistiques.html).
} 


\section{$5 \quad$ Empirical Studies}

\subsection{Investigation on Courts' Removal Decisions}

As recalled in subsection 2.2, the government justified courts' removal in 2008 on efficiency criteria. Before turning to the econometric analysis, let us recall that the government did not remove labor courts in "départements" with only one labor court. The rationale was to insure a minimum access to justice all over the French territory.

Considering this very fact, the following analysis will focus solely on labor courts that were in "départements" with several courts (245 courts among 271). We shall refer to these courts as removable courts.

\subsubsection{Empirical Strategies}

In order to understand the determinants of the government's choice on courts' removal, we compare two sets of removable courts: those which have been effectively removed, and those which have remained. We propose to compare them on a list of observables we collected, and which are summarized in table 1 . Conditional summary statistics for the two groups are displayed in table 2.

First, we collect legal characteristics, namely the duration of terminated cases (in months) for 2007 (duration), and the average number of cases in the past four years (averageCases). Second, we also consider economic and demographic variables: the unemployment rate at the zone d'emploi 'slevel (unemployment), the log GDP per capita at the département's level $(\ln (g d p))$, and the population of the département $(p o p)$. Third, we take into account the proportion of socialist deputies in the electoral districts of the city of the removable court $($ propPS $)$. Fourth, we also control for the composition of the court $(\operatorname{prop} N R){ }^{26}$

Table 2 displays the descriptive statistics for the two groups of removable courts. This table shows that the two groups of removable courts -the removed courts and the maintained courts - are similar in all observables but one. Indeed, a two-group mean comparison test suggests that the two categories of courts differ in the average number of cases they received in the past years preceding the reform. This confirms stylized facts presented in the previous section: removed courts dealt with fewer cases.

\footnotetext{
${ }^{26}$ Lay judges at the French labor courts are elected by both employees and employers. There is an equal number of judges elected by employers and by employees. Lists are proposed by both employers' federations and employees' unions. Most of the time, there is a common list from the employers' federations, while employees' unions compete. We control for the proportion of judges (at court level) elected by employees who are members of the two non-reformist unions, i.e. the two most leftist unions (CGT, FO) considered as the most demanding and "pro-employee" unions. The three other main unions are considered as "reformist", i.e. more willing to negotiate with employers' federations.
} 
Table 1: Summary Statistics of the cross-section dataset

\begin{tabular}{|c|c|c|c|c|c|c|}
\hline Variable & Meanings & Mean & Std. Dev. & Min. & Max. & $\mathbf{N}$ \\
\hline unemployment & Zone d'emploi's unemployment rate in 2007 & 8.273 & 2.086 & 4.175 & 14.675 & 245 \\
\hline $\ln (g d p)$ & Departmental GDP per capita in 2005 (log of $€$ ) & 10.089 & 0.227 & 9.85 & 11.231 & 245 \\
\hline $\ln ($ popDen $)$ & Département's population density (log) & 4.408 & 1.0387 & 3.136 & 9.962 & 245 \\
\hline duration & Average duration of cases in the court (months) & 10.983 & 3.820 & 3.2 & 25.4 & 245 \\
\hline distance & Distance to the nearest court within the département $(\mathrm{km})$ & 42.501 & 23.269 & 2.8 & 137 & 245 \\
\hline propPS & Proportion of Socialist deputies in the court's city (\%) & 0.2204 & 0.3911 & 0 & 1 & 245 \\
\hline $\operatorname{prop} N R$ & Proportion of non-reformist lay judges in the court (\%) & 0.5439 & 0.120 & 0.188 & 0.929 & 245 \\
\hline $\ln ($ averageCases $)$ & Annual average number of new cases 2004-2007 (log) & 5.793 & 0.909 & 3.323 & 8.466 & 245 \\
\hline remov & After reform status ( 1 if removed, 0 otherwise) & 0.253 & 0.436 & 0 & 1 & 245 \\
\hline
\end{tabular}

Sources: Ministry of Justice, INSEE, National Assembly

Table 2: Conditional mean of the cross-section dataset

\begin{tabular}{lccc}
\hline \hline \multirow{2}{*}{ Variable } & \multicolumn{2}{c}{ Mean } & p-value \\
\cline { 2 - 3 } & Maintained courts & Removed courts & \\
\hline unemployment & 8.195 & 8.314 & 0.692 \\
ln $($ gdp $)$ & 10.079 & 10.137 & 0.084 \\
ln(popDen $)$ & 4.368 & 4.551 & 0.239 \\
duration & 11.018 & 11.016 & 0.997 \\
distance & 43.659 & 39.084 & 0.181 \\
propPS & 0.246 & 0.1774 & 0.235 \\
propNR & 0.549 & 0.538 & 0.529 \\
ln(averageCases) & 6.120 & 4.858 & 0.000 \\
remov & 0 & 1 & - \\
\hline \hline
\end{tabular}


Table 3: Summary Statistics of the panel dataset

\begin{tabular}{|c|c|c|c|c|c|}
\hline Variable & Meanings & Mean & Std. Dev. & Min. & Max. \\
\hline duration & Average duration of terminated cases (months) & 11.05 & 3.288 & 2.7 & 28.6 \\
\hline $\ln ($ newCases $)$ & Annual Average number of cases (log) & 6.147 & 0.866 & 4.248 & 9.765 \\
\hline unemployment & Zone d'emploi's unemployment rate & 9.052 & 2.226 & 4.03 & 16.9 \\
\hline $\ln (p o p)$ & Departmental population (log of hundred thousand inhabitants) & 1.849 & 0.727 & -0.277 & 3.252 \\
\hline $\ln (g d p)$ & Regional GDP per capita (log of $€$ ) & 10.190 & 0.2005 & 9.9144 & 10.844 \\
\hline$R$ & After reform status ( 1 if receiving, 0 otherwise) & 0.1166 & 0.321 & 0 & 1 \\
\hline relativeBurden & Relative size of the court(s) the receiving court takes on & 9.890 & 22.407 & 0 & 135.6 \\
\hline yearref & Number of years after the reform (0 before 2009) & 1.112 & 1.449 & 0 & 4 \\
\hline distance & Distance between receiving and removed courts $(\mathrm{km})$ & 10.742 & 20.922 & 0 & 124 \\
\hline$R \times$ relativeBurden & Interaction of $R$ and relativeBurden & 4.396 & 15.727 & 0 & 135.587 \\
\hline$R \times$ yearref & Interaction of $R$ and yearref & 0.292 & 0.889 & 0 & 4 \\
\hline$R \times$ distance & Interaction of $R$ and distance & 4.774 & 14.935 & 0 & 135.587 \\
\hline$R \times$ relativeBurden $\times$ distance & Interaction of $R$, relativeBurden and distance & 178.876 & 707.874 & 0 & 8398.341 \\
\hline$R \times$ relativeBurden $\times$ yearref & Interaction of $R$, relativeBurden and yearref & 10.989 & 43.348 & 0 & 542.35 \\
\hline départage & Rate of départage (between 0 and 100) & 15.021 & 11.017 & 0 & 77.3 \\
\hline winRate & Proportion of cases won by plaintiffs (between 0 and 1 ) & 0.3827 & 0.0912 & 0.0795 & 0.8629 \\
\hline
\end{tabular}

Source: French Ministry of Justice, INSEE. 
In order to assess which factors played a decisive role in the government's choice, we now turn to an econometric investigation. The empirical goal consists in exploring whether, controlling for court's activity, other factors may have explained the government's decision. The binary variable remov accounts for these decisions: it is equal to one in case of effective removal and to zero otherwise (remov stands for removal). To do so, we consider the following probit model:

$$
\begin{array}{r}
\operatorname{remov}_{i}^{*}=\beta_{0}+\beta_{1} \ln (g d p)_{i}+\beta_{2} \text { unemployment }_{i}+\beta_{3} \ln \left(\text { averageCases }_{i}\right)+\beta_{4} \ln \left(\text { popDen }_{i}\right) \\
+\beta_{5} \text { distance }_{i}+\beta_{6} \text { duration }_{i}+\beta_{7} \text { propP }_{i}+\beta_{8} \text { prop } R_{i}+\epsilon_{i}
\end{array}
$$

with

$$
\text { remov }= \begin{cases}1 & \text { if } \text { remov }^{*}>0 \\ 0 & \text { otherwise }\end{cases}
$$

where $\epsilon$ is an random term drawn from a standardized normal distribution.

We use this specification to investigate the removal decision on the 245 removable courts, among which 62 were effectively removed.

\subsubsection{Main Results}

Table 4: Probit Estimation of Courts' Removal Decision

\begin{tabular}{lcccc}
\hline \hline \multicolumn{1}{c}{ Variable } & Coefficient & (Std. Err.) & Marg. effect & (Std.Err) \\
\hline unemployment & $0.1335^{* *}$ & $(0.0637)$ & $0.01486^{*}$ & $(0.0071)$ \\
$\ln ($ gdp) & 0.4048 & $(1.109)$ & 0.0451 & $(0.126)$ \\
$\ln ($ popDen) & 0.0531 & $(0.245)$ & 0.0059 & $(0.0272)$ \\
duration & 0.00813 & $(0.0328)$ & 0.0009 & $(0.00364)$ \\
$\ln ($ averageCases) & $-2.463^{* * *}$ & $(0.308)$ & $-0.2741^{* * *}$ & $(0.0668)$ \\
distance & $-0.0149^{* * *}$ & $(0.0054)$ & $-0.00165^{* *}$ & $(0.00075)$ \\
propPS & -0.3899 & $(0.3299)$ & -0.0434 & $(0.0357)$ \\
propNR & $-1.919^{*}$ & $(1.042)$ & $-0.2136^{*}$ & $(0.118)$ \\
Intercept & 8.920 & $(10.928)$ & - & - \\
\hline \multicolumn{5}{c}{245} \\
\hline N & \multicolumn{5}{c}{-63.782} \\
Log-likelihood & \multicolumn{5}{c}{0.000} \\
P-value of the likelihood & \multicolumn{5}{c}{0.5398} \\
Pseudo-R ${ }^{2}$ & \multicolumn{5}{c}{} \\
\hline \hline
\end{tabular}

$\dagger$ Significance level: $* * *$ significant at $1 \%$ level $* *$ significant at $5 \%$ level $*$ significant at $10 \%$ level. (Robust standard errors in parentheses.)

Table 4 shows the results of the probit estimation. We report the p-value associated to the Pearson statistics, and the pseudo $R^{2}$. Both statistics indicate that our specification fits well the data. We also provide the correlation matrix of the independent variables in table 8 in 
Appendix 2.

First, regarding courts' activity, the average number of new cases between 2004 and 2007 plays a significant role in determining courts' removal. Courts which received more cases were indeed less likely to be removed. In fact, an increase in one percent of the number of new cases is associated to a decrease of 0.27 percentage point to be removed. The strong marginal effect indicates that the government intentionally targeted small labor courts. Regarding the second legal variable, it seems that case duration did not affect the removal decisions: the government did not seek to remove courts with higher delays.

Second, as far as economic and demographic variables are concerned, we observe a positive relationship between the unemployment level and the probability of removal: courts in zones d'emploi with higher levels of unemployment were more likely to be removed. On the other side, the level of GDP per capita did not seem to have played a significant role in the decision of the policy-makers.

The positive effect of unemployment on the probability of removal must be interpreted in terms of deviation to the mean: courts in zones d'emploi with higher unemployment levels were more likely to be removed than their counterparts located in zones d'emploi with lower unemployment rates. This may suggest a will to concentrate efforts on the most dynamic areas of the country, as economic activity is likely to be more intense in areas with low levels of unemployment. This may lead to more labor relationships and a stronger need to have labor courts in these areas. In addition, areas with high unemployment levels are often rural areas whose industrial restructuring is difficult. The low perspective of business development may have been a factor to decide court's removal.

Third, our estimation suggests that the distance to the nearest court within the department was decisive in the decision-making: more isolated removable courts have been less likely to be removed than their counterparts. The marginal effect indicates that an increase of one kilometer between a removable court and the nearest court decreases by 0.17 percentage points the probability of being removed. This effect is consistent with the government's willingness to limit the decrease in courts' accessibility.

Fourth, we do not find any evidence suggesting that the proportion of socialist deputies influenced the government's decision. It seems that the government did not discriminate between labor courts in socialist and in conservative cities. Nor do we find strong evidence suggesting that the proportion of non-reformist judges did affect policy makers' decision to remove a court. The coefficient associated to the proportion of non-reformist councillors is indeed only significant at the $90 \%$ confidence level. Areas where non-reformist judges are highly represented are generally zones under industrial restructuring. The result is then consistent with our previous interpretation: the reform might have aimed at concentrating efforts on the most dynamic areas of the country.

Result 1 In a nutshell, our findings indicate that the 2008 judicial reform mainly targeted smaller and less isolated courts in "départements" with high unemployment. These results suggest that the government was consistent with its goal to rationalize the French judicial system under the constraint of justice accessibility. 


\subsection{Reform's Impact on Caseload and Case Duration}

In order to investigate the reform's impact on the number of new cases received by courts, we propose two strategies. First, we construct counterfactuals to evaluate whether the demand for litigation decreased as a consequence of the increased distance to labor courts. Second, we propose an econometric estimation of the reform's impact on both the number of new cases and case duration.

\subsubsection{Counterfactuals}

The first and most natural approach to assess whether the decrease in the courts' accessibility reduced the demand for litigation consists in comparing the observed demand for litigation in 2009 (i.e. after the reform) to the demand for litigation that would have taken place without the reform. Such a comparison would require the construction of a counterfactual to establish whether the demand of litigation contracted.

Our counterfactual analysis relies on the three groups of courts described in section 3 (unaffected courts, removed courts and receiving courts), and proceeds as follows. First, we use courts which were not affected by the reform to estimate the natural growth rate in the demand for litigation between 2007 and 2009. Second, we use this growth rate to create counterfactuals of the receiving courts if the demand for litigation had not been affected by the reform. Third, we compare errors between the counterfactuals and the real data for both the control group (i.e. unaffected courts) and the receiving courts to determine whether the demand for litigation decreased in receiving courts.

In order to construct a counterfactual, we use the group of courts which were not affected by the reform as a control group. The underlying idea consists in using the control group to understand how the demand for litigation naturally evolved between 2007 and 2009, and to construct a counterfactual of courts affected by the reform in the light of this evolution. ${ }^{27}$ Note that we are able to do so because section 4.2 showed that receiving and unaffected courts displayed similar trends prior to the reform.

First, we compute the evolution rate of the demand for litigation for the control group between 2007 and $2009(E R)$. It is defined by:

$$
E R=\frac{1}{J} \sum_{i \in J} \frac{\text { newCases }_{2009, i}-\text { newCases }_{2007, i}}{\text { newCases }}
$$

where $J$ denotes both the set and the number of labor courts not affected by the reform.

This evolution rate allows us to construct counterfactuals of the receiving courts in 2009 if the demand for litigation had not been affected by the reform $\left(C F^{R}\right)$, i.e. if receiving courts had received their own demand for litigation together with the demand for litigation of the removed court as if nothing happened.

\footnotetext{
${ }^{27}$ We choose 2007 rather than 2008 to make our counterfactual analysis, because the graph in the previous section showed a decrease in the number of new claims brought to the removed courts in 2008 . It might be that litigants started anticipating the reform in 2008, and this impacted the decision to open new claims. We therefore consider cases in 2007 as the benchmark.
} 


$$
C F_{i}^{R}=E R \times \text { new }^{2} \text { ases }_{2007, i}+E R \times \text { sumReceived }_{2007, i}
$$

where sumReceived $_{2007, i}$ stands for the sum of new cases in 2007 in removed labor courts that court $i$ took on.

For the sake of comparison, we also create counterfactuals of the courts which were not affected by the reform $\left(C F^{C}\right)$.

$$
C F_{i}^{C}=E R \times \text { newCases }_{2007, i}
$$

Note that the second term of the counterfactual disappeared because, by definition, courts which were not affected by the reform did not expand their geographical competences.

The computation of the evolution rate $(E R)$ yields an increase of $21.4 \%$ in the demand for litigation between 2007 and 2009 in the courts which were not affected by the reform. After the construction of the counterfactuals, we compute the normalized difference between the observed number of new cases and the counterfactual $\left(\Delta_{i}\right)$.

$$
\Delta_{i}=\frac{\text { newCases } 2009, i}{-C F_{i}}
$$

Moment statistics of these normalized differences displayed in table 5 suggest that the two distributions are very close: both the mean and the variance of these distributions are similar. Nevertheless, the mean of the receiving courts is lower than the mean of the unaffected courts. This result is driven by the fact that the real number of cases in 2009 is lower than what the counterfactual would have predicted for receiving courts. This finding would depict a contraction of the demand for litigation. In order to confirm this hypothesis, we run a twogroup mean comparison test, but we fail at rejecting the null hypothesis of mean equality.

\begin{tabular}{cccc}
\hline Group & Observations & Mean & St. Dev. \\
\hline Receiving courts & 53 & -0.1698 & 0.0385 \\
Unaffected courts & 148 & -0.09659 & 0.0276 \\
\hline
\end{tabular}

Table 5: Moment Statistics of the normalized differences

\subsubsection{Econometrics}

Empirical Strategy To deepen our previous analysis, we now investigate the impact of the 2008 reform on two variables that reflect court activities, i.e. the number of new cases per year and duration of terminated cases. To do so, we use the panel database presented in table 3, which provides information of each labor court from 2004 to 2012.

A major concern when determining a reform's impact lies in the potential selection of courts which were affected by the reform. As the above empirical analysis has shown, removed courts 
were not randomly selected. This also implies that courts which expanded their geographical competences were not randomly selected either. Nevertheless, the panel structure of our data allows us to capture the potential heterogeneity of courts by introducing fixed effects. To empirically assess the reform's impact on the number of new cases per year (newCases), and on the duration of terminated cases (duration), we construct a variable $r_{i t}$ which accounts for the reform status (equal to 1 if court $i$ has expanded its geographical competences at time $t$, and equal to 0 otherwise).

The general specification for the two dependent variables is defined by:

$$
\begin{aligned}
& \text { duration }_{i t}=\gamma_{0}+\gamma_{1} \ln \left(\text { newCases }_{i t}\right)+\gamma_{2} r_{i t}+\gamma_{3} r_{i t} \times \text { relativeBurden }_{i}+\gamma_{4} \text { departage }_{i t} \\
& +\gamma_{5} \ln (g d p)_{i t}+\gamma_{6} \text { unemployment } t_{i t}+\gamma_{7} \ln (\text { pop })_{i t}+\mu_{i}+\alpha_{t}+u_{i t} \\
& \ln \left(\text { newCases }_{i t}\right)=\beta_{0}+\beta_{1} \text { duration }_{i t}+\beta_{2} r_{i t}+\beta_{3} r_{i t} \times \text { relativeBurden }_{i}+\beta_{4} \text { winRate }_{i t} \\
& +\beta_{5} \ln (g d p)_{i t}+\beta_{6} \text { unemployment }_{i t}+\beta_{7} \ln (\text { pop })_{i t}+\mu_{i}^{\prime}+\alpha_{t}^{\prime}+v_{i t}
\end{aligned}
$$

where $u_{i t}$ and $v_{i t}$ are two normally distributed random terms, $\mu_{i}$ and $\mu_{i}^{\prime}$ are court fixed effects, $\alpha_{t}$ and $\alpha_{t}^{\prime}$ are year fixed effects.

Few comments can be made in the light of this general specification. First, both specifications include the $r_{i t}$ variable, which accounts for the reform, since we aim at measuring the reform's impact on both the duration of terminated cases and on the inflow of new cases. Second, we create an interaction term between the reform and relativeBurden. The variable relativeBurden represents the relative size of the removed courts a receiving court has taken on. A relativeBurden equal to 50 means that the number of new claims dealt by removed courts between 2004 and 2007 represents 50\% of the receiving court's activity level between 2004 and 2007. The interaction term depicts the effect of the reform conditionally on the burden a receiving court faces. ${ }^{28}$ Third, both specifications contain macroeconomic controls (logarithm of the gdp per inhabitant, unemployment rate, and the logarithm of the population). Fourth, specification 7 includes the rate of départage, which is very likely to affect the duration of terminated cases, since this procedure expands the legal process. ${ }^{29}$ Départage is however very unlikely to affect the number of new cases since it is unpredictable, and does not affect the very content of the decision. ${ }^{30}$ Fifth, we consider the potential impact of win rates on the number of new cases brought to the court. We suspect indeed that parties take into account past information to form expectations about their own chances of winning a case. Recent works suggest indeed that increased chances of winning at the labor courts are associated with more settlement (Desrieux and Espinosa [2015]). WinRate corresponds to

\footnotetext{
${ }^{28}$ Our specifications do not include relativeBurden separately, since it already contains court fixed effects and relativeBurden is time-invariant. Including relativeBurden would generate collinear explanatory variables.

${ }^{29}$ Let us recall that départage is a special procedure, in which lay judges ask a professional judge to intervene to help them to make a decision. Several reasons can justify départage (the need to clarify a legal argument, disagreement between lay judges about a decision or about the amount of damages...). Lay judges can ask such an intervention but do not need to motivate the precise reason. This procedure increases duration: while claims without départage are terminated on average in 15 months, the duration increases up to 25 months when départage is required (De Maillard Taillefer and Timbart [2009]).

${ }^{30}$ The win rate for plaintiffs is about 3 to 1 with or without départage (Desrieux and Espinosa [2015]).
} 
the number of cases which were favorably decided by lay judges over the total number of cases dealt by the court this year. Since judges' workload does not depend on the nature of their final decision, it is very unlikely for the win rate to have any impact on the duration of terminated cases. ${ }^{31}$

Estimation Method The estimation of the previous equations system raises some empirical challenges. Our general specification allows indeed both left-hand side variables to have an impact on each other. This specification is mainly motivated by the fact that litigants take into account delays before going to court, and the number of new claims is also likely to affect workload and judges' efficiency. The interdependence of the two equations constitutes an empirical issue for the standard OLS estimations. Indeed, if our general specification turned to be structurally correct, separate OLS estimations would be inconsistent (Greene [2003], Cameron and Trivedi [2005]). In order to investigate the relevance of this hypothesis, we run standard separate OLS estimations, and we display the results in table 9 in Appendix 2 .

Considering that the coefficients associated to the duration and the number of new cases are both significant when they are used as regressors, we propose to rely on a 3SLS estimation strategy. ${ }^{32}$ The 3SLS estimation combines IV and GLS estimation techniques. As in standard IV estimations, the number of instruments must be at least equal to the number of endogenous variables. The order condition in a 3SLS setting can also be stated in these terms: "The number of exogenous variables not appearing in [each] equation must be as great as the number of endogenous variables appearing on the RHS of this equation" (Wooldridge [2002]).

In the present case, the 3SLS estimation requires one instrument for each dependent variable. The general specification proposes two instruments. First, we propose to instrument the number of new claims by the win rate. As explained in the discussion of the general specification, we believe that the win rate is likely to influence the decision of litigants to open a claim (instrument relevance condition), but is not likely to affect duration (exclusion condition). Similarly, we believe that the rate of départage influences the duration of terminated cases but not the decision to open new claims (except through the channel of delays). Identification of our system of equations for the 3SLS estimation is therefore insured by these two variables. Results of the 3SLS estimations confirm moreover that our instruments are strongly correlated with the instrumented variables. The following analysis will thus focus on the 3SLS estimations. Note that the 3SLS estimation provided close results to the OLS estimates.

To go one step further, we wonder whether the impacts of the reform were different according to time and space considerations. ${ }^{33}$ To address this issue, we explore two subspecifications.

\footnotetext{
${ }^{31}$ We also run our estimations with the lagged value of WinRate, and results were qualitatively similar. We display the results for the contemporaneous values of WinRate to maximize the number of used observations.

${ }^{32}$ Estimation of a system of related questions could also be obtained through 2SLS, or Full Information Maximum Likelihood techniques. Note however that the 3SLS technique is more efficient than the 2SLS estimation in presence of heteroscedasticity. The FIML estimation is as efficient as the 3SLS method if disturbances are normally distributed. We prefer to use the 3SLS estimation since the FIML makes an additional assumption.

${ }^{33}$ One could think that the reform has also a conditional impact according to the changes of GDP per capita. However, the local GDP could also be impacted by the reform that changes the conditions on the labour market (by making dismissal more difficult to challenge). In this regard, our estimation must be seen
} 
First, we allow the reform to have a conditional impact on the number of years the reform has been enforced. To do so, we introduce a variable numYear $s_{t}$, which is equal to zero before the reform and equal to the number of years the reform has been in place between 2009 and 2012. A full description of the system of equations is given in Appendix 3. Second, we consider the possibility that the reform had an impact conditional on the distance between the receiving and the removed courts. We add a variable which accounts for the number of kilometers between the two kinds of courts (denoted distance $_{i}$ ). ${ }^{34}$

Results Table 9 in Appendix 2 shows the results of the OLS estimation. Tables 10, 11, and 12 in Appendix 2 display results of the general, time, and spatial specifications respectively. Because our specifications include several interaction terms, we also display graphically the marginal effects of the reform conditional on the relative burden receiving courts take on. Figures 6 and 7 in Appendix 5 display the conditional marginal effect (CME) for both the duration of terminated cases and the log of the number of new cases for all specifications.

In order to visualize the reform's impact on both dependent variables according to each specification, we summarize results in table 6 . The second and the third columns show whether the null hypothesis of the first row associated to each dependent variable is rejected in each specification. Rejecting the null hypothesis associated to duration means that the reform has, on average, increased the duration of terminated cases. Rejecting the second null hypothesis implies that the number of new cases has, on average, decreased because of the reform. ${ }^{35}$

General Comments First of all, one can remark that both dependent variables are significant in the OLS estimation when they are used as regressors, which suggests that the 3SLS estimation is more appropriate for our investigation. The coefficient associated to duration looses its significance in the 3SLS estimation, but still remains very close to the $10 \%$ threshold. The signs of the coefficients remain constant across estimations. In order to interpret the net effect of the reform for the OLS estimation, we display two graphs in Appendix 5 (Figure 5). These graphs are very similar to the net effect found with the subsequent 3SLS estimations. The 3SLS estimation takes into account both direct and indirect effects of the right-hand side variables.

Duration The reform's impact on the duration of terminated cases is derived from the 3SLS estimations, and is displayed in figure 6 in Appendix 5. The overall impact is composed

as capturing an overall effect of the reform: it estimates both the direct reform's effect (i.e. the decrease in the demand for litigation resulting from the increased costs in access to justice) and the indirect effects of the reform (i.e. changes in the number of new cases resulting from the new conditions in the labor market). However, as a robustness check, we have investigated whether the reform has had a conditional impact according to the level of GDP of the CPH's region in 2008. We found no evidence suggesting that richer regions have been affected in a different way by the reform.

${ }^{34}$ The variable distance $_{i}$ has two special features. First, it is equal to zero for unaffected courts. This coding is arbitrary, but does not affect our results since distance $_{i}$ is never used as a regressor, but is always used in an interaction term which would yield to zero scores to unaffected courts. For more details, see the appendix. Second, distance ${ }_{i}$ is equal to the weighted average distance if the receiving courts take on the geographical competence of two removed courts. We take the average number of new cases between 2004 and 2007 for the weight of the removed courts.

${ }^{35}$ Here, 'on average' refers to the average relative burden receiving courts have received (weighted by their average number of new cases between 2004 and 2007). 


\begin{tabular}{|c|c|c|c|}
\hline \multicolumn{2}{|c|}{ National Average Effect } & Duration & New Cases \\
\hline \multicolumn{2}{|c|}{$H_{0}$} & $\begin{array}{l}\text { The reform did not } \\
\text { increase the duration. }\end{array}$ & $\begin{array}{l}\text { The reform did not decrease } \\
\text { the demand for litigation. }\end{array}$ \\
\hline \multicolumn{2}{|c|}{ General Specification } & $H_{0}$ not rejected & $H_{0}$ rejected \\
\hline & 2009 & $H_{0}$ not rejected & $H_{0}$ rejected \\
\hline Time & 2010 & $H_{0}$ not rejected & $H_{0}$ rejected \\
\hline \multirow[t]{2}{*}{ Specification } & 2011 & $H_{0}$ not rejected & $H_{0}$ rejected \\
\hline & 2012 & $H_{0}$ not rejected & $H_{0}$ rejected \\
\hline \multicolumn{2}{|c|}{ Spatial Specification } & $H_{0}$ not rejected & $H_{0}$ rejected \\
\hline \multicolumn{2}{|c|}{ Conclusion } & $\begin{array}{l}\text { Duration did not increase } \\
\text { at the national average. }\end{array}$ & $\begin{array}{c}\text { Number of claims did decrease } \\
\text { at the national average. }\end{array}$ \\
\hline \multicolumn{2}{|c|}{ Local Effects } & Duration & New Cases \\
\hline \multicolumn{2}{|c|}{ General Specification } & $\begin{array}{l}\text { Increase for courts } \\
\text { receiving a great } \\
\text { burden. }\end{array}$ & $\begin{array}{l}\text { Contraction of the demand } \\
\text { in courts receiving a great } \\
\text { burden. }\end{array}$ \\
\hline \multirow{2}{*}{\multicolumn{2}{|c|}{$\begin{array}{c}\text { Time } \\
\text { Specification }\end{array}$}} & Increase for courts & Contraction occurred as \\
\hline & & $\begin{array}{c}\text { receiving a great burden } \\
\text { in } 2011 .\end{array}$ & soon as 2009 . \\
\hline \multicolumn{2}{|c|}{ Spatial Specification } & $\begin{array}{l}\text { Close receiving courts } \\
\text { have increased duration. }\end{array}$ & - \\
\hline
\end{tabular}

Table 6: Impact of the reform on the duration of terminated cases and the number of new cases. 
of both the direct and indirect impacts. The direct impact corresponds to the coefficients associated to $r_{i t}$ and $r_{i t} \times$ relativeBurden $n_{i}$ in column Duration of table 10 . The indirect effect corresponds to the impact of the reform on the number of new cases, which is in turn passed on the duration. Because both the dependent variables are included in the set of explanatory variables for the other dependent variable, we face a feedback effect. Appendix 3 shows how to derive the total impact of the reform on both dependent variables.

The first graph in figure 6 displays the marginal effect of the reform conditional on the relative burden a court receives (General Specification). As one can see, we cannot reject the null hypothesis that the reform did not increase the duration of terminated cases in the receiving courts, whatever the relative burden they received. Indeed, the horizontal zero line is below the lower curve, defined as the lowest bound of the $95 \%$ confidence interval, for some values of relative burden. This result suggests that courts which were receiving a large burden have suffered from an increase in delays. Nevertheless, the national average effect of the reform, displayed by the vertical line, is not statistically significant. ${ }^{36}$

The second graph of figure 6 (upper right) shows the reform's marginal effect in the spatial specification, i.e. conditionally on the distance between courts. Because the impact of the reform is conditioned on both the relative burden of the receiving courts and the distance with the removed courts, we displayed the marginal effect computed for each court. Indeed, since both relativeBurden and distance were uniquely defined by one single receiving court, we were able to display the marginal effect of each court on one single graph. The effect is obviously non-linear in the relative burden. One detects however that few courts might have suffered from an increase in duration, but we cannot distinguish a clear pattern. The third graph also displays the marginal effect of the spatial specification, but plots the marginal effects with regard to the distance between the receiving and the removed courts. A clearer pattern appears: closer courts were more likely to have an increase in delays, while more distant courts were more likely to have lower case duration. This effect might be due to the number of new cases: if the report of the demand for litigation was affected by the distance, it might be that close courts have been congested, while more distant courts have received more additional means by the state than the reported demand for litigation would have required. We then compute the national average effect of the reform, taking into consideration the role of the distance. Our computations, detailed in Appendix 4, yield a national average marginal effect of 0.3276 , with an associated p-value equal to 0.132 . The reform does not seem to have increase (on average) the duration of terminated cases at national level.

Third, the time specification yields the four remaining graphs in figure 6. Each graph is conditioned on a specific year, which induces straightforward interpretations. The marginal effects displayed for 2009 and 2010 are never statistically different from zero, which suggests that courts did not suffer from an increased duration in these two years. Graphs for 2011 and especially 2012 suggest however that receiving courts who took on a large burden (more than $50 \%$ of their capacity) incurred an increase in the duration of terminated cases. The apparition of the effect in 2011 and 2012 is not surprising, since the duration focuses on terminated cases only, and congestion effects may take time to be reflected in the data. Nevertheless, we do not find an overall increase at the national average, since the marginal effect is not statistically different from zero at the national average.

\footnotetext{
${ }^{36}$ See the appendix for the computation of the national average effects.
} 
Result 2 (a) At the national aggregated level, the 2008 judicial reform did not have any impact on case duration in receiving courts.

(b) When removed courts were at close distance from their receiving court, duration might have increased in this receiving court. The effect is not large enough to appear at the national level.

(c) The higher the burden of a receiving court, the more duration might have increased, especially in 2011 and 2012. This effect is not large enough to appear at the national level.

New Cases Did the removal of courts decrease the demand for litigation when distance to go to court became higher, as feared by the opponents to the reform? In order to investigate this question, we ask whether receiving courts which took on claims from a removed court representing $\mathrm{x} \%$ of their own size (i.e. their relative burden), also increased their number of new cases by $x \%$. To interpret the estimation results, we plot the marginal effect of the reform conditioned on the relative burden together with a diagonal line which represents a full report of the demand for litigation. All graphs are displayed in figure 7 in Appendix 5 . The upper left graph, which displays the marginal effect given by the general specification yields a first set of results. One can observe that the average marginal effect is always below the $100 \%$ line, which suggests that no court had a full report of the demand for litigation. We are however not able to confirm this hypothesis for courts which received a small relative burden. The contraction of the demand for litigation seems to be increasing with the relative burden: the bigger the burden receiving courts had to deal with, the more the demand for litigation contracted. At the national average, receiving courts took on a burden equal to $22.34 \%$ of their size. However, their demand increased only by $14 \%$ after the reform. This suggests that the demand for litigation contracted by the difference (about 10 percentage points).

The spatial specification yields similar results. The demand for litigation seems to have contracted after the reform. Still, we are not able to confirm this hypothesis for courts receiving a small burden. It seems nevertheless that the decrease of the demand has been more drastic for courts with higher relative burdens. The third graph, which plots the marginal effects on the distance, shows no clear pattern. At the national weighted average, we find that receiving courts received a burden of $22.34 \%$ of their previous capacity, but that the demand for litigation in those courts increased only by $13.52 \%{ }^{37}$

Third, as far as the time specification is concerned, we observe the same pattern as in the two previous specifications: the demand for litigation has contracted after the reform. Only tiny differences can be observed between the four graphs (2009, 2010, 2011, 2012). The effect becomes clearly significant from 2010. Moreover, the national average effect is not statistically different across years, which suggests that the reform's effect on the number of new cases was immediate.

Result 3 (a) At the national aggregated level, the demand for litigation decreased after the implementation of the reform.

(b) The contraction was more severe in receiving courts which took on a relatively high burden.

\footnotetext{
${ }^{37}$ The demand for litigation at the national average is statistically different from the full report at the $99 \%$ confidence level. The associated test yields a $\mathrm{z}$-value equal to -3.94 .
} 
(c) The contraction occurred as soon as 2009, i.e. immediately after the reform was implemented.

Control Variables In order to interpret the remaining control variables, we compute the marginal effects taking into account the feedback effects. Table 7 displays their marginal impact on both dependent variables. All specifications yield similar results. First, the GDP is positively associated with the number of new cases, which suggests that courts are more active in richer areas. These results can be interpreted as follows: a higher GDP means that economic activity is flourishing and more people may be employed. This increase in employment relationships may lead to more labor conflicts between employers and employees, compared to areas with low economic activity. In addition, finding a job or finding a new employee may be easier in areas with a high GDP level, since they attract firms and workers. This may lead to more job turnover and potentially more conflicts when employment relationships end. ${ }^{38}$ Another explanation could be that the GDP impacts the number of collective dismissals: the lower the GDP, the more collective dismissals we observe, and the fewer cases are brought to labor courts. Indeed, in France, collective dismissals are brought to civil courts (tribunaux d'instance) and not to labor courts that only deal with individual conflicts. ${ }^{39}$ Second, the unemployment level is negatively correlated with the duration of terminated cases: Delays are shorter in localities with higher unemployment levels. One can think that areas with long-term unemployment are areas with high economic difficulties or industrial restructuring. There are fewer employment relationships and then fewer labor conflicts. A consequence is that the caseload, i.e. the "stock" of cases to be examined, is lower in these labor courts. The average duration for a new case to be heard can then be lower. A complementary explanation can be that a high level of unemployment may mean past collective dismissals. As previously mentioned, collective dismissals are brought to civil courts, since labor courts only deal with individual dismissals. This may explain why they face a lighter caseload. Last, we could also think that a high level of unemployment means that there were many labor conflicts in the past. Judges in labor courts may have faced a large diversity of situations and may have gained more experience to analyse a claim. Such experience effects may explain why duration (to make a decision about a case) decreases with unemployment.

Finally, the size of the population seems to be positively correlated with the duration of cases, but the coefficient is not statistically different from zero. Let us recall here that $\ln ($ pop $)$ does not measure population but rather population variations (because of the fixed-effects). Moreover, these variations are not relative to the working population but to the whole population. This may explain why $\ln (p o p)$ does not appear as significant.

\footnotetext{
${ }^{38}$ Some references support this interpretation. For instance, the French INSEE website documents that richer regions attract more people (http ://www.insee. $f r / f r / f f c / i p w e b / i p 1501 / i p 1501 . p d f)$. In addition, Marinescu shows that the number of dismissals that are challenged in France is positively correlated with economic growth: any additional point of economic growth leads to 0,59 point increase in new labor cases (Marinescu [2005], p.121).

${ }^{39}$ Source: Official Report from the French Ministry of Economic and Financial Affairs entitled Note du Trésor, nº137, october 2014.
} 


\begin{tabular}{ccccccc}
\hline \hline Specification & \multicolumn{2}{c}{ General } & \multicolumn{2}{c}{ Spatial } & \multicolumn{2}{c}{ Time } \\
\hline Marginal Effects & duration & $\ln ($ newCases $)$ & duration & $\ln$ (newCases) & duration & $\ln ($ newCases $)$ \\
\hline $\ln ($ gdp) & -2.9261 & $0.4819^{* *}$ & -3.309 & $0.5115^{* *}$ & -3.006 & $0.480^{* *}$ \\
& $(-1.23)$ & $(1.97)$ & $(-1.39)$ & $(2.08)$ & $(-1.26)$ & $(1.96)$ \\
unemployement & $-0.3221^{* * *}$ & 0.00542 & $-0.3325^{* * *}$ & 0.00459 & $-0.3196^{* * *}$ & 0.0054 \\
& $(-2.69)$ & $(0.44)$ & $(-2.79)$ & $(0.37)$ & $(-2.67)$ & $(0.44)$ \\
$\ln$ (pop) & 5.894 & 0.1776 & 5.426 & 0.1204 & 6.262 & 0.1790 \\
& $(1.47)$ & $(0.43)$ & $(1.35)$ & $(0.29)$ & $(1.56)$ & $(0.43)$ \\
\hline \hline
\end{tabular}

Table 7: Marginal Effects of local economic variables.

\section{Concluding Remarks}

The 2008 French judiciary reform removed about $20 \%$ of labor courts, i.e. about $5.8 \%$ of the demand for litigation in 2007. This reform came out after months of harsh discussions between the government and the Parliament. Advocates of the reform claimed that it would allow to reduce costs, and would not impact access to justice. On the contrary, opponents argued that it would decrease the demand for litigation, and increase court congestion. In this paper, we investigate these two arguments. We first look at the determinants of courts' removal. We find that the reform targeted low-level activity courts, and that political representation (i.e. whether the local representative belongs to a left- or right-wing party) did not affect the decision to remove courts. Our second concern was about the consequences of the reform, both at the national and local levels. We find that the reform did not increase case duration at the aggregated national level. Yet, at the local level, case duration increased in courts taking on a large burden from closed courts. We also look at the demand for litigation (i.e. the number of new claims). At the national level, the reform decreased this demand. More precisely, we find that this decrease was observed as early as 2009 in areas where courts were removed, and where courts received a high level of new claims coming from suppressed courts. This suggests that the organization of the judiciary is not neutral on the demand for litigation. Unlike previous theoretical works, which concluded that court reduction would lead to mixed results on the demand for litigation, we found clear evidence documenting the decrease in the demand for litigation.

The originality of our work is to propose a first empirical evaluation of the reduction in the number of courts. Naturally, it calls for extensions to explore this question in other contexts, but it may serve as a benchmark for similar reform projects. As a first step, our study still proposes some elements to contribute to the debate about the organization of the judiciary. Fears are often expressed about the lack of proximity, and on the risk for some litigants to be prevented to sue because of the increased distance to courts. Our results suggest indeed that the demand for litigation has been affected by both the distance and the burden courts have taken on. In other words, potential litigants in areas where a court has been removed have been less likely to open a claim the further and the smaller the new court. Furthermore, the limited increase in delays we detect in courts receiving a great burden in 2012 indicates that congestion effects appear. The transfer of judges from the removed courts to the receiving courts may have decreased the average productivity of the court. This interpretation is in line with Dimitrova-Grajzl, Grajzl, Sustersic, and Zajc [2012b]: the relationship between the 
number of judicial staff and the courts' output might not necessarily be straightforward.

In spite of these contributions, our work has some limits. First, our results show that the reform mainly targeted small courts (i.e. courts with a low demand for litigation) in areas with high unemployment levels. However, the process of court selection does not necessarily entail that the reform was welfare-enhancing. These courts had indeed low levels of activity, but had also shorter delays compared to the other labor courts. Moreover, this decision may raise problems regarding equality of justice access and public service delivery in some economically affected areas. As a consequence, our results do not allow to conclude about the legitimacy and the relevance of the retained criteria. We only stress that the decision was made on economic criteria (such as the number of claims) and not on political considerations. Second, our findings need to be interpreted with caution. We cannot conclude too rapidly on the global (in)efficiency of the reform. For instance, our study does not discuss the global cost of the reform (direct costs such as the reallocation of some judges to other courts, or indirect costs such as the impacts of courts' removal on the local economic activity in some cities). In the same way, the global benefits of the reform (financial gains through the removal of some courts, fewer civil servants to hire in future, ...) are difficult to evaluate precisely. Another difficulty regarding the welfare impact of the reform is that we are not able to distinguish between meritorious and frivolous claims. The decrease in the demand for litigation is then difficult to interpret as we do not know how this decrease affected the composition of claims brought to courts. A welfare analysis would also require to investigate the quality of courts' decisions. Discussions on appeal or reversal rates might provide some insight to understand whether the judiciary better succeeds in solving conflicts among litigants and to interpret the law in a proper manner. In addition, we can question to what extent delays are a good proxy for justice quality. Higher delays may result from more care devoted to each case. Referring to previous works, Mitsopoulos and Pelagidis [2007] state that "when justice is served with great delay, other qualitative measures of the judiciary's efficiency also worsen". Furthermore, the welfare implications of demand for litigation may be ambiguous: a higher demand may also result from more trust in institutions, and be a natural consequence of economic development and improved human well-being (Eisenberg, Kalantry, and Robinson [2013]). In addition, data are only available until 2012 (i.e. four years after the reform): our effects are at best medium-run effects that may be different in the long run. Our study also focuses on labor courts, and effects may change in other courts such as civil courts. Moreover, we cannot collect information about the number of conflicts per se (i.e. the total number of conflicts that appeared and the eventual out-of-the-court settlement). One could imagine that the reform also impacts these two dimensions. Last, we focus on case duration and caseload to evaluate the consequences of the reform. Other quantitative or qualitative criteria could be explored in the future (such as judges' productivity, the use of alternative dispute resolution mechanisms, the global level of trust in justice, ...). Still more broadly, it would be worth investigating the impact of the reform on the labor market. Indeed, the enforcement of labor law is part of the total labor costs, and removing courts in areas with high unemployment rates might be detrimental in the long-run. In this respect, the potential increase in delays that appears in the data since 2012 might be an obstacle to a well functioning labor market. Worse, as we emphasized in section 4.2 , litigants in areas where courts were removed have faced a double issue: they now have to go further, and they face longer delays. The degradation of justice accessibility in these areas might have affected the labor supply in a permanent way. These questions need to be deeply investigated by 
public authorities, and call for further research.

\section{Compliance with Ethical Standards}

This research was not funded by any institution. Data are publicly available on the websites of the Ministry of Justice and INSEE (French National Institute for Statistics). The authors declare that they have no conflict of interest. This article does not contain any studies with human participants or animals performed by any of the authors. 


\section{References}

Daron Acemoglu and Simon Johnson. Unbundling Institutions. Journal of Political Economy, 113(5):949-995, October 2005.

Michael Beenstock and Yoel Haitovsky. Does the Appointment of Judges Increase the Output of the Judiciary? International Review of Law and Economics, 24(3):351-369, September 2004

Juan Carlos Botero, Rafael La Porta, Florencio López-de Silanes, Andrei Shleifer, and Alexander Volokh. Judicial Reform. The World Bank Research Observer, 18(1):61-88, 2003.

Juan Carlos Botero, Rafael La Porta, and Florencio López-de Silanes. The Regulation of Labor. The Quarterly Journal of Economics, 119(4):1339-1382, November 2004.

Richard T. Boylan. Salaries, Turnover, and Performance in the Federal Criminal Justice System. Journal of Law and Economics, 47(1):75-92, 2004.

Edgardo Buscaglia. Judicial Corruption in Developing Countries: Its Causes and Economic Consequences. Technical report, United Nations Office for Drug Control and Crime Prevention, 2001.

Edgardo Buscaglia, M. Dakolias, and W.E. Ratliff. Judicial Reform in Latin America. Stanford University, 1995.

A Colin Cameron and Pravin K Trivedi. Microeconometrics: Methods and Applications. Cambridge university press, 2005.

CEPEJ. Study on the Functioning of Judicial Systems in the EU Member States. Technical report, 2014a.

CEPEJ. Report on European Judicial Systems - Edition 2014 (2012 data): Efficiency and Quality of Justice. Technical report, 2014b.

Nathalie Chappe. Demand for Civil Trials and Court Congestion. European Journal of Law and Economics, 33(2):343-357, 2012.

Nathalie Chappe and Marie Obidzinski. The Impact of the Number of Courts on the Demand for Trials. International Review of Law and Economics, 37:121-125, 2014.

Matthieu Chemin. The impact of the judiciary on entrepreneurship: Evaluation of Pakistan's Access to Justice Programme. Journal of Public Economics, 93(1-2):114-125, February 2009

Matthieu Chemin. Does Court Speed Shape Economic Activity? Evidence from a Court Reform in India. Journal of Law, Economics and Organization, 28(3):460-485, August 2012 .

Stephen J. Choi, Mitu Gulati, and Eric Posner. Are Justices Overpaid? A Skeptical Response to the Judicial Salary Debate. Journal of Legal Analysis, 1(1):47-117, 2009a. 
Stephen J. Choi, Mitu Gulati, and Eric Posner. Judicial Evaluations and information forcing: Ranking state high courts and their judges. Duke Law Journal, 58:1333-1381, 2009b.

Stephen J. Choi, Mitu Gulati, and Eric Posner. Professionals or Politicians: The Uncertain Empirical Case for an Elected Rather than Appointed Judiciary. Journal of Law, Economics, and Organization, 26(2):290-336, 2010.

Stephen J. Choi, Mitu Gulati, and Eric Posner. How Well do Measures of Judicial Ability Translate Into Performance? International Journal of Law and Economics, 33:37-52, 2011.

Stephen J. Choi, Mitu Gulati, and Eric Posner. What Do Federal District Judges Want? An Analysis of Publications, Citations, and Reversals. Journal of Law, Economics and Organization, 28(3):518-549, August 2012.

Cour des comptes. Rapport public annuel 2015. Technical report, 2015.

Frank B. Cross and Stefanie Lindquist. Judging the judges. Duke Law Journal, 58:1383-1437, 2009.

Maria Dakolias. The judicial sector in latin america and the carribean elements of reform. World Bank Technical Paper, 319, 1996.

Maria Dakolias. Court performance around the world: A comparative perspective. Yale Human Rights and Development Journal, 2(1), 1999.

Maria Dakolias and S. Said. Judicial reform, a process of change through pilot courts. Legal and Judicial Reform Unit, Legal Department, 1999.

Laure De Maillard Taillefer and Odile Timbart. Les affaires prud'homales en 2007. Technical Report 105, Infostat, Ministère de la Justice, 2009.

Claudine Desrieux and Romain Espinosa. Do Employers Fear Unions in Labor Courts? Theory and Evidence from French Labor Courts. Working Paper, 2015.

Fatih Deyneli. Analysis of Relationship Between Efficiency of Justice Services and Salaries of Judges with Two-stage DEA Method. European Journal of Law and Economics, 34(3): 477-493, 2012.

Valentina Dimitrova-Grajzl, Peter Grajzl, Janez Sustersic, and Katarina Zajc. Judicial Incentives and Performance at Lower Courts: Evidence from Slovenian Judge-Level Data. Review of Law \& Economics, 8(1):215-252, August 2012a.

Valentina Dimitrova-Grajzl, Peter Grajzl, Janez Sustersic, and Katarina Zajc. Court output, judicial staffing, and the demand for court services: Evidence from Slovenian courts of first instance. International Review of Law and Economics, 32(1):19-29, 2012b.

Simeon Djankov, Rafael La Porta, Florencio López-de Silanes, and Andrei Shleifer. Courts. The Quarterly Journal of Economics, 118(2):453-517, May 2003.

Doing Business. Doing business 2015: Going beyond efficiency. Technical report, the World Bank, 2014. 
Theodore Eisenberg, Sital Kalantry, and Nick Robinson. Litigation as a Measure of Wellbeing. DePaul Law Review, 62:247-292, 2013.

ENCJ. Judicial Reform in Europe, 2011-2012. Technical report, 2012.

European Commission. The 2014 EU Justice Scoreboard. Technical report, European Commission, 2014.

Nuno Garoupa. Globalization and Deregulation of Legal Services. International Review of Law and Economics, 38(S):77-86, 2014.

Nuno Garoupa, Anna Dalla Pellegrina, and Mattia Suardi. Do Judges Respond to Monetary Incentives? An Empirical Investigation. Working Paper, 2015.

Conceicao Gomes. The Transformation of the Portuguese Judicial Organization: between Efficiency and Democracy. Utrecht Law Review, 2007.

William H Greene. Econometric Analysis, 5th. Ed. Upper Saddle River, NJ, 2003.

IMF. Judicial System Reform in Italy. Technical report, IMF Working Paper, 2014.

Rafael La Porta, Florencio Lopez-de Silanes, Andrei Shleifer, and Robert W. Vishny. Law and Finance. Journal of Political Economy, 106(6):1113-1155, December 1998.

Alain Lacabarats. L'avenir des juridictions du travail : Vers un tribunal prud'homal du $X X I^{\text {eme }}$ siècle. Technical report, Rapport à Mme la Garde des Sceaux, Ministre de la Justice, 2014.

Claire S. H. Lim. Preferences and Incentives of Appointed and Elected Public Officials: Evidence from State Trial Court Judges. The American Economic Review, 103(4):13601397, 2013.

Elaine Mak. Balancing Territoriality and Functionality; Specialization as a Tool for Reforming Jurisdiction in the Netherlands, France and Germany. International Journal for Court Administration, 1(2):2-9, 2008.

Ioana Marinescu. Coûts et procédures de licenciement, croissance et innovation technologique Coûts et procédures de licenciement, croissance et innovation technologique. PhD thesis, Ecole des Hautes Etudes en Sciences Sociales, 2005.

Didier Marshall. Les juridictions du du XXI $I^{\text {eme }}$ siècle. Technical report, Rapport Mme la Garde des Sceaux, ministre de la Justice, 2013.

Eric Maskin and Jean Tirole. The Politician and the Judge: Accountability in Government. American Economic Review, 94(4):1034-1054, September 2004.

Michael Mitsopoulos and Theodore Pelagidis. Does staffing affect the time to dispose cases in Greek courts? International Review of Law and Economics, 27:219-244, 2007.

Charles (de) Montesquieu. The Spirit of Laws. 1748.

OECD. Judicial performance and its determinants: a cross-country perspective. Technical report, OECD Economic Policy Papers, 2013. 
Richard A Posner. Creating a Legal Framework for Economic Development. World Bank Research Observer, 13(1):1-11, February 1998.

Richard A. Posner. Is the Ninth Circuit Too Large? A Statistical Study of Judicial Quality. The Journal of Legal Studies, 29(2):711-719, June 2000.

Larry E Ribstein. Ethical Rules, Agency Costs and Law Firm Structure. Virginia Law Review, 84:1707-1759, 1998.

Sénat. La réforme de la carte judiciaire: une occasion manquée. Technical report, Rapport d'Information de Mme Nicole Borvo Cohen-Seat et M. Yves Détraigne, fait au nom de la commission des lois, 2012.

Adam Smith. Lectures on Jurisprudence, volume 5. Glasgow Edition of Works, 1762.

Frank Stephen. Lawyers, Markets and Regulation. Edward Elgar Publishers, London, 2013.

Frank H. Stephen. The European Single Market and the Regulation of the Legal Profession: an Economic Analysis. Managerial and Decision Economics, 23(3):115-125, 2002.

Frans Van Djik and Dumbrava Horatius. Judiciary in Times of Scarcity: Retrenchment and Reform. International Journal for Court Administration, 5(1):15-24, 2013.

David Webber. Good Budgeting, Better Justice : Modern Budget Practices for the Judicial Sector. Law and development working paper series, 3, 2007.

Jeffrey M. Wooldridge. MIT Press, Cambridge, Massachusetts, 2002.

World Bank. Improving the Performance of Justice Institutions. Technical report, 2011.

World Bank. The world bank: New directions in justice reform. Technical report, 2012.

Albert Yoon. Pensions, Politics, and Judicial Tenure: An Empirical Study of Federal Judges, 1869-2002. American Law and Economics Review, 8(1):143-180, 2006. 


\section{A Appendix 1: Maps of Judicial System}

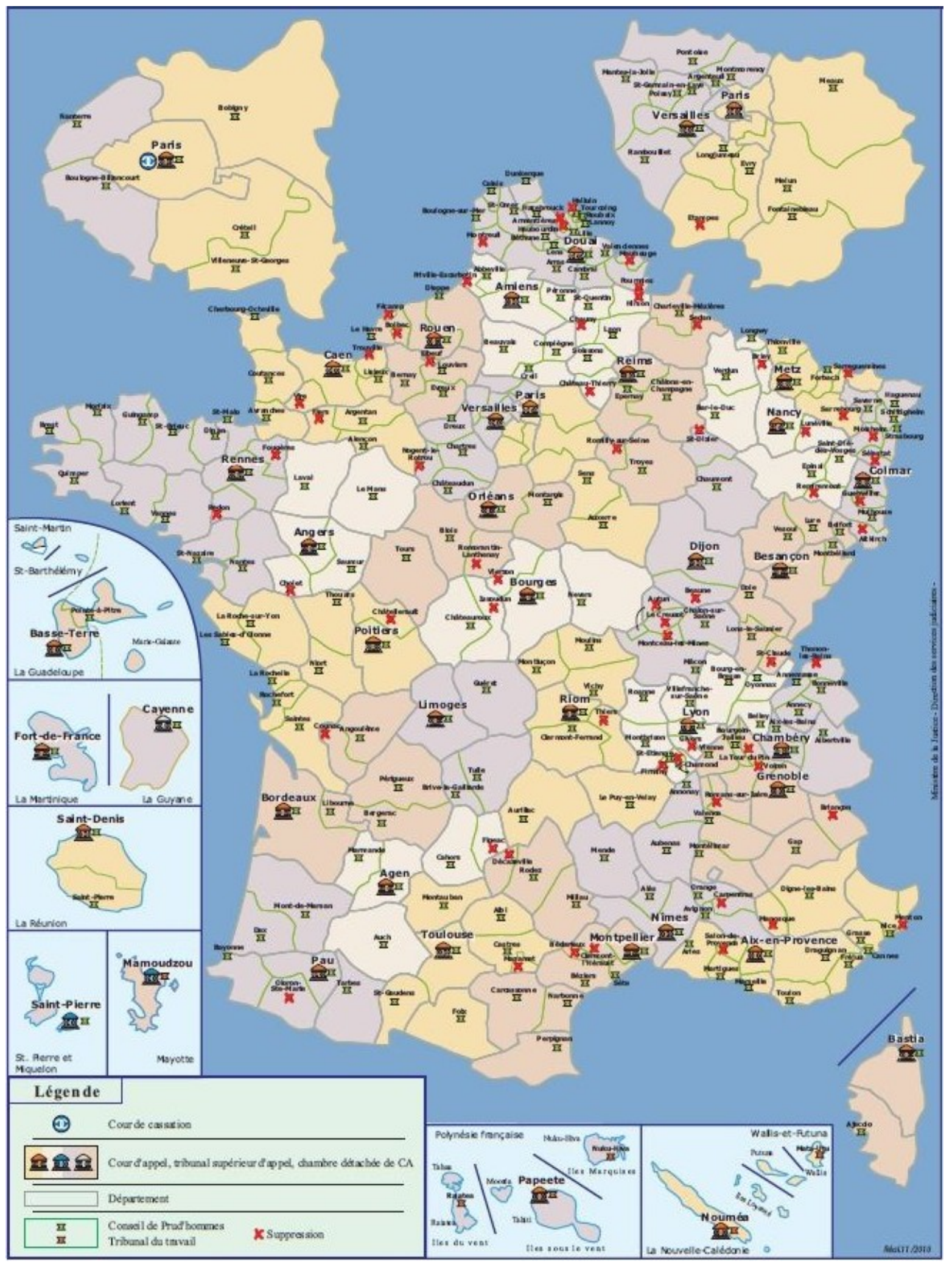

Figure 3: French courts before the reform and removals during the reform 


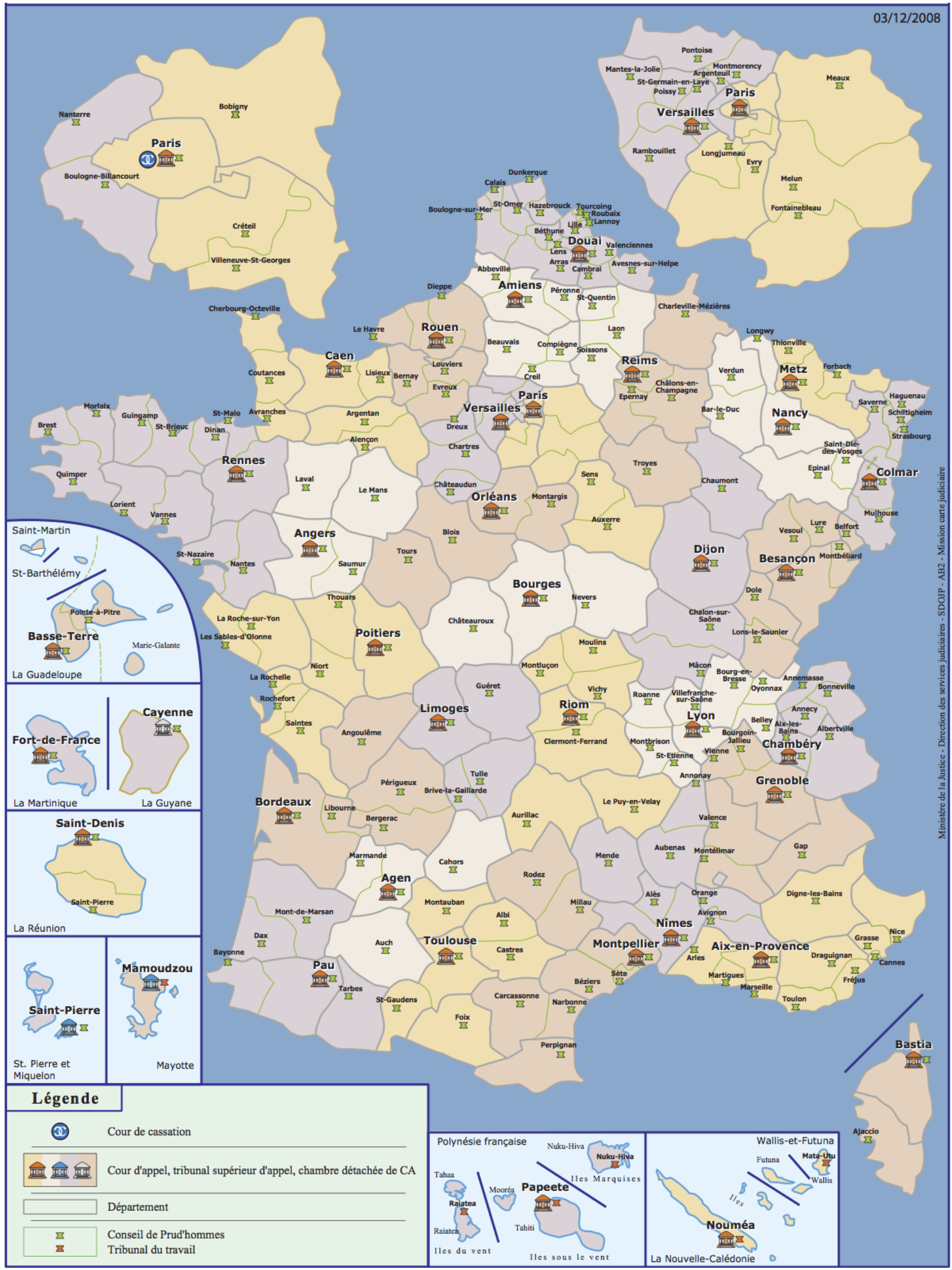

Figure 4: French courts after the reform 


\section{B Appendix 2: Tables and Figures}

\begin{tabular}{|c|c|c|c|c|c|c|c|c|}
\hline & 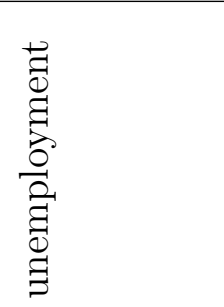 & 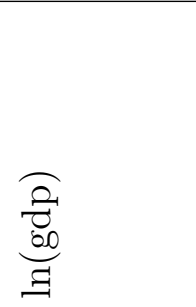 & $\begin{array}{l}\overparen{a} \\
0 \\
\Xi \\
\Xi\end{array}$ & 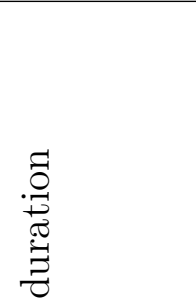 & 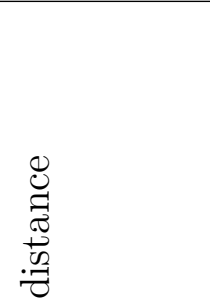 & $\begin{array}{l}\tilde{D} \\
\tilde{D}_{1} \\
0 \\
0 \\
0\end{array}$ & 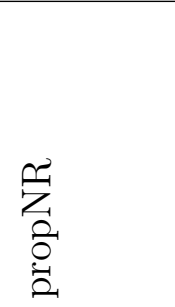 & 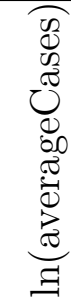 \\
\hline $\ln (\operatorname{gdp})$ & $\begin{array}{c}-0.1591^{* * *} \\
(0.0096)\end{array}$ & & & & & & & \\
\hline $\ln (\mathrm{pop})$ & $\begin{array}{l}-0.0983 \\
(0.1112)\end{array}$ & $\begin{array}{c}0.8782^{* * *} \\
(0.000)\end{array}$ & . & & & & & \\
\hline duration & $\begin{array}{c}0.1025^{*} \\
(0.0965)\end{array}$ & $\begin{array}{l}-0.0636 \\
(0.3030)\end{array}$ & $\begin{array}{l}-0.0464 \\
(0.4532)\end{array}$ & . & & & & \\
\hline distance & $\begin{array}{l}-0.1007 \\
(0.1159)\end{array}$ & $\begin{array}{l}-0.0487 \\
(0.4481)\end{array}$ & $\begin{array}{l}-0.0755 \\
(0.2389)\end{array}$ & $\begin{array}{l}-0.1126^{*} \\
(0.0785)\end{array}$ & . & & & \\
\hline propPS & $\begin{array}{c}0.0980 \\
(0.1123)\end{array}$ & $\begin{array}{c}-0.1283^{* *} \\
(0.0372)\end{array}$ & $\begin{array}{c}-0.1264^{* *} \\
(0.0402)\end{array}$ & $\begin{array}{l}-0.0091 \\
(0.8828)\end{array}$ & $\begin{array}{c}0.0453 \\
(0.4804)\end{array}$ & . & & \\
\hline propNR & $\begin{array}{c}0.2105^{* * *} \\
(0.0006)\end{array}$ & $\begin{array}{c}0.0563 \\
(0.3618)\end{array}$ & $\begin{array}{c}0.1000 \\
(0.1050)\end{array}$ & $\begin{array}{c}0.1317^{* *} \\
(0.0324)\end{array}$ & $\begin{array}{l}-0.0202 \\
(0.7530)\end{array}$ & $\begin{array}{c}0.1217^{* *} \\
(0.0482)\end{array}$ & . & \\
\hline $\ln$ (averageCases) & $\begin{array}{c}0.0645 \\
(0.2964)\end{array}$ & $\begin{array}{c}0.0114 \\
(0.8533)\end{array}$ & $\begin{array}{c}0.0630 \\
(0.3080)\end{array}$ & $\begin{array}{c}0.0861 \\
(0.1631)\end{array}$ & $\begin{array}{c}-0.1543^{* *} \\
(0.0156)\end{array}$ & $\begin{array}{l}-0.0106 \\
(0.8643)\end{array}$ & $\begin{array}{l}-0.0466 \\
(0.4510)\end{array}$ & . \\
\hline
\end{tabular}

Table 8: Correlation matrix of the independent variables of the probit specification. 


\begin{tabular}{|c|c|c|c|c|}
\hline \multirow[b]{2}{*}{ Variable } & \multicolumn{2}{|c|}{ duration } & \multicolumn{2}{|c|}{$\ln ($ newCases) } \\
\hline & Coefficient & (Z-stat) & Coefficient & (Z-stat) \\
\hline $\ln ($ newCases $)$ & $-1.1228^{* * *}$ & $(-4.36)$ & & \\
\hline départage & $0.0521^{* * *}$ & $(6.36)$ & & \\
\hline duration & & & $-0.00813^{* * *}$ & $(-2.97)$ \\
\hline winRate & & & $-0.3201^{* * *}$ & $(-3.74)$ \\
\hline$r$ & 0.2183 & $(0.58)$ & 0.04297 & $(1.15)$ \\
\hline$r \times$ relativeBurden & 0.0127 & $(1.45)$ & $0.00524^{* * *}$ & $(8.18)$ \\
\hline $\ln (g d p)$ & -2.607 & $(-0.69)$ & $0.7966^{* * *}$ & $(3.53)$ \\
\hline unemployment & $-0.3303^{* *}$ & $(-2.04)$ & 0.00728 & $(0.58)$ \\
\hline $\ln (p o p)$ & 6.8556 & $(1.12)$ & $0.5599 * * *$ & $(7.75)$ \\
\hline Court FE & \multicolumn{2}{|c|}{ Yes } & \multicolumn{2}{|c|}{ Yes } \\
\hline Year FE & \multicolumn{2}{|c|}{ Yes } & \multicolumn{2}{|c|}{ Yes } \\
\hline $\mathrm{N}$ & \multicolumn{2}{|c|}{1817} & \multicolumn{2}{|c|}{1817} \\
\hline Within $\mathrm{R}^{2}$ & \multicolumn{2}{|c|}{0.1745} & \multicolumn{2}{|c|}{0.2203} \\
\hline P-value & \multicolumn{2}{|c|}{0.000} & \multicolumn{2}{|c|}{0.000} \\
\hline
\end{tabular}

$\dagger$ Significance level: $* * *$ significant at $1 \%$ level ${ }^{* *}$ significant at $5 \%$ level *significant at $10 \%$ level.

Table 9: Results of the OLS estimation. (Robust clustered standard errors.)

\begin{tabular}{|c|c|c|c|c|}
\hline \multirow[b]{2}{*}{ Variable } & \multicolumn{2}{|c|}{ duration } & \multicolumn{2}{|c|}{$\ln ($ newCases) } \\
\hline & Coefficient & (Z-stat) & Coefficient & (Z-stat) \\
\hline $\ln ($ newCases $)$ & $-8.689^{* * *}$ & $(-3.79)$ & & \\
\hline départage & $0.04706^{* * *}$ & $(6.74)$ & & \\
\hline duration & & & -0.01641 & $(-1.63)$ \\
\hline winRate & & & $-0.2940 * * *$ & $(-4.30)$ \\
\hline$r$ & 0.2966 & $(0.80)$ & 0.01872 & $(0.62)$ \\
\hline$r \times$ relativeBurden & $2.0547^{* * *}$ & $(3.69)$ & $0.00565^{* * *}$ & $(9.57)$ \\
\hline $\ln (g d p)$ & 1.261 & $(0.39)$ & $0.4338^{*}$ & $(1.77)$ \\
\hline unemployment & $-0.275^{*}$ & $(-1.81)$ & 0.000131 & $(0.01)$ \\
\hline $\ln (p o p)$ & 7.437 & $(1.47)$ & 0.2743 & $(0.66)$ \\
\hline Court FE & \multicolumn{2}{|c|}{ Yes } & \multicolumn{2}{|c|}{ Yes } \\
\hline Year FE & \multicolumn{2}{|c|}{ Yes } & \multicolumn{2}{|c|}{ Yes } \\
\hline $\mathrm{N}$ & \multicolumn{2}{|c|}{1817} & \multicolumn{2}{|c|}{1817} \\
\hline Within $\mathrm{R}^{2}$ & \multicolumn{2}{|c|}{0.5070} & \multicolumn{2}{|c|}{0.9535} \\
\hline P-value & \multicolumn{2}{|c|}{0.000} & \multicolumn{2}{|c|}{0.000} \\
\hline
\end{tabular}

${ }^{\dagger}$ Significance level: $* * *$ significant at $1 \%$ level $* *$ significant at $5 \%$ level *significant at $10 \%$ level.

Table 10: Results of the 3SLS estimation. 


\begin{tabular}{|c|c|c|c|c|}
\hline \multirow[b]{2}{*}{ Variable } & \multicolumn{2}{|c|}{ duration } & \multicolumn{2}{|c|}{$\ln ($ newCases) } \\
\hline & Coefficient & (Z-stat) & Coefficient & (Z-stat) \\
\hline $\ln ($ newCases $)$ & $-8.654^{* * *}$ & $(-3.78)$ & & \\
\hline départage & $0.0472^{* * *}$ & $(6.77)$ & & \\
\hline duration & & & -.01642 & $(-1.64)$ \\
\hline winRate & & & $-.2942^{* * *}$ & $(-4.31)$ \\
\hline$r$ & 0.6958 & $(0.97)$ & .04574 & $(0.79)$ \\
\hline$r \times$ relativeBurden & $0.03992^{* *}$ & $(2.14)$ & $.00515^{* * *}$ & $(4.52)$ \\
\hline$r \times$ numYears & -0.16004 & $(-0.65)$ & -.01081 & $(-0.54)$ \\
\hline$r \times$ relativeBurden $\times$ numYears & 0.00583 & $(1.21)$ & .000201 & $(0.51)$ \\
\hline $\ln (g d p)$ & 1.1520 & $(0.36)$ & $.4311^{*}$ & $(1.75)$ \\
\hline unemployment & $-0.2726^{*}$ & $(-1.80)$ & .000179 & $(0.01)$ \\
\hline $\ln (p o p)$ & 7.8103 & $(1.54)$ & .2818 & $(0.67)$ \\
\hline Court FE & \multicolumn{2}{|c|}{ Yes } & \multicolumn{2}{|c|}{ Yes } \\
\hline Year FE & \multicolumn{2}{|c|}{ Yes } & \multicolumn{2}{|c|}{ Yes } \\
\hline $\mathrm{N}$ & \multicolumn{2}{|c|}{1817} & \multicolumn{2}{|c|}{1817} \\
\hline Within $\mathrm{R}^{2}$ & \multicolumn{2}{|c|}{0.5091} & \multicolumn{2}{|c|}{0.9535} \\
\hline P-value & \multicolumn{2}{|c|}{0.000} & \multicolumn{2}{|c|}{0.000} \\
\hline
\end{tabular}

$\dagger$ Significance level: $* * *$ significant at $1 \%$ level ${ }^{* *}$ significant at $5 \%$ level ${ }^{*}$ significant at $10 \%$ level.

Table 11: Results of the 3SLS estimation - time subspecification.

\begin{tabular}{|c|c|c|c|c|}
\hline \multirow[b]{2}{*}{ Variable } & \multicolumn{2}{|c|}{ duration } & \multicolumn{2}{|c|}{$\ln ($ newCases) } \\
\hline & Coefficient & (Z-stat) & Coefficient & (Z-stat) \\
\hline $\ln ($ newCases $)$ & $-8.926 * * *$ & $(-3.81)$ & & \\
\hline départage & $0.04653^{* * *}$ & $(6.59)$ & & \\
\hline duration & & & -.01687 & $(-1.67)$ \\
\hline winRate & & & -.2881 & $(-4.21)$ \\
\hline$r$ & -0.6646 & $(-0.88)$ & -0.08743 & $(-1.51)$ \\
\hline$r \times$ relativeBurden & $0.1039^{* * *}$ & $(4.24)$ & $0.00813^{* * *}$ & $(5.94)$ \\
\hline$r \times$ distance & 0.02280 & $(1.41)$ & $0.00255^{* *}$ & $(2.14)$ \\
\hline$r \times$ relativeBurden $\times$ distance & $-0.00116^{* * *}$ & $(-3.10)$ & $-0.000060^{* *}$ & $(-2.02)$ \\
\hline $\ln (g d p)$ & 1.256 & $(0.38)$ & $0.4556^{*}$ & $(1.85)$ \\
\hline unemployment & $-0.2916^{*}$ & $(-1.90)$ & -.00102 & $(-0.08)$ \\
\hline $\ln (p o p)$ & 6.501 & $(1.27)$ & 0.2120 & $(0.51)$ \\
\hline Court FE & \multicolumn{2}{|c|}{ Yes } & \multicolumn{2}{|c|}{ Yes } \\
\hline Year FE & \multicolumn{2}{|c|}{ Yes } & \multicolumn{2}{|c|}{ Yes } \\
\hline $\mathrm{N}$ & \multicolumn{2}{|c|}{1817} & \multicolumn{2}{|c|}{1817} \\
\hline Within $\mathrm{R}^{2}$ & \multicolumn{2}{|c|}{0.4984} & \multicolumn{2}{|c|}{0.9536} \\
\hline P-value & \multicolumn{2}{|c|}{0.000} & \multicolumn{2}{|c|}{0.000} \\
\hline
\end{tabular}

$\dagger$ Significance level: $* * *$ significant at $1 \%$ level $* *$ significant at $5 \%$ level ${ }^{*}$ significant at $10 \%$ level.

Table 12: Results of the 3SLS estimation - spatial subspecification. 


\section{Appendix 3: Marginal effects}

General specification The general specification is given by the following equation system:

$$
\begin{aligned}
& \text { duration }_{i t}=\gamma_{0}+\gamma_{1} \ln \left(\text { newCases }_{i t}\right)+\gamma_{2} r_{i t}+\gamma_{3} r_{i t} \times \text { relativeBurden }_{i}+\gamma_{4} \text { departage }_{i t} \\
& +\gamma_{5} \ln (g d p)_{i t}+\gamma_{6} \text { unemployment } t_{i t}+\gamma_{7} \ln (\text { pop })_{i t}+\mu_{i}+\alpha_{t}+u_{i t} \\
& \ln \left(\text { newCases }_{i t}\right)=\beta_{0}+\beta_{1} \text { duration }_{i t}+\beta_{2} r_{i t}+\beta_{3} r_{i t} \times \text { relativeBurden }_{i}+\beta_{4} \text { winRate }_{i t} \\
& +\beta_{5} \ln (g d p)_{i t}+\beta_{6} \text { unemployment }_{i t}+\beta_{7} \ln (\text { pop })_{i t}+\mu_{i}^{\prime}+\alpha_{t}^{\prime}+v_{i t}
\end{aligned}
$$

Note that these two equations do not include a control for relativeBurden only, because this would be collinear with the court fixed effects.

The marginal effects of the reform are:

$$
\begin{aligned}
\frac{\partial \text { duration }_{i t}}{\partial r_{i t}} & =\underbrace{\gamma_{1} \frac{\partial \ln \left(\text { newCases }_{i t}\right)}{\partial r_{i t}}}_{\text {Indirect Effect }}+\underbrace{\gamma_{2}+\gamma_{3} \text { relativeBurden }_{i}}_{\text {Direct Effect }} \\
\frac{\partial \ln \left(\text { newCases }_{i t}\right)}{\partial r_{i t}} & =\underbrace{\beta_{1} \frac{\partial d \text { duration }}{\partial t}}_{\text {Indirect Effect }}+\underbrace{\beta_{i t}}_{\text {Direct Effect }}+\beta_{3} \text { relativeBurden }_{i}
\end{aligned}
$$

Substituting each left-hand side in the right-hand side of the other equation:

$$
\begin{aligned}
\left(1-\gamma_{1} \beta_{1}\right) \frac{\text { duration }_{i t}}{\partial r_{i t}} & =\gamma_{1} \beta_{2}+\gamma_{1} \beta_{3} \text { relativeBurden }_{i}+\gamma_{2}+\gamma_{3} \text { relativeBurden }_{i} \\
\left(1-\beta_{1} \gamma_{1}\right) \frac{\partial \ln \left(\text { newCases }_{i t}\right)}{\partial r_{i t}} & =\beta_{1} \gamma_{2}+\beta_{1} \gamma_{3} \text { relativeBurden }_{i}+\beta_{2}+\beta_{3} \text { relativeBurden }_{i}
\end{aligned}
$$

Which yields:

$$
\begin{aligned}
\frac{\partial \text { duration }_{i t}}{\partial r_{i t}} & =\frac{\gamma_{2}+\gamma_{1} \beta_{2}+\left(\gamma_{3}+\gamma_{1} \beta_{3}\right) \text { relativeBurden }_{i}}{1-\gamma_{1} \beta_{1}} \\
\frac{\partial \ln \left(\text { newCases }_{i t}\right)}{\partial r_{i t}} & =\frac{\beta_{2}+\beta_{1} \gamma_{2}+\left(\beta_{3}+\beta_{1} \gamma_{3}\right) \text { relativeBurden }_{i}}{1-\beta_{1} \gamma_{1}}
\end{aligned}
$$

Time Specification The time specification include more interaction variables with the reform dummy. The time specification is defined by:

$$
\begin{aligned}
\text { duration }_{i t}= & \gamma_{0}+\gamma_{1} \ln \left(\text { newCases }_{i t}\right)+\gamma_{2} r_{i t}+\gamma_{3} r_{i t} \times \text { relativeBurden }_{i}+\gamma_{4} \text { departage }_{i t} \\
& +\gamma_{5} \ln (\text { gdp })_{i t}+\gamma_{6} \text { unemployment }_{i t}+\gamma_{7} \ln (\text { pop })_{i t}+\gamma_{8} r_{i t} \times \text { numYear }_{t} \\
& +\gamma_{9} r_{i t} \times \text { numYear }_{t} \times \text { relativeBurden }_{i}+\mu_{i}+\alpha_{t}+u_{i t}
\end{aligned}
$$

$$
\begin{aligned}
\ln \left(\text { newCases }_{i t}\right)= & \beta_{0}+\beta_{1} \text { duration }_{i t}+\beta_{2} r_{i t}+\beta_{3} r_{i t} \times \text { relativeBurden }_{i}+\beta_{4} \text { winRate }_{i t} \\
& +\beta_{5} \ln \left([\text { gdp })_{i t}+\beta_{6} \text { unemployment }_{i t}+\beta_{7} \ln (\text { pop })_{i t}+\beta_{8} r_{i t} \times \text { numYears }_{t}\right. \\
& +\beta_{9} r_{i t} \times \text { numYear }_{t} \times \text { relativeBurden }_{i}+\mu_{i}^{\prime}+\alpha_{t}^{\prime}+v_{i t}
\end{aligned}
$$


Note that these two equations do not include a control for numYears only because this would

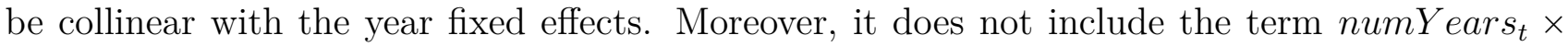

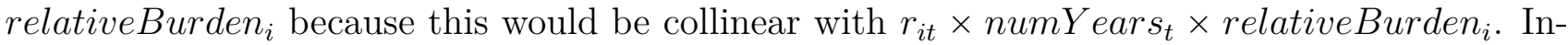
deed, the number of years is equal to zero for all courts before 2009 (numYears). Moreover, the relative burden courts receive is equal to zero for all non-receiving courts (relativeBurden). Multiplying the interaction term by $r_{i t}$ would not affect the values of the new variable, which would create perfect collinearity.

The marginal effects of the reform are given by:

$$
\begin{aligned}
& \frac{\partial \text { duration }_{i t}}{\partial r_{i t}}=\underbrace{\gamma_{1} \frac{\partial \ln \left(\text { newCases }_{i t}\right)}{\partial r_{i t}}}_{\text {Indirect Effect }} \\
& +\underbrace{\gamma_{2}+\gamma_{3} \text { relativeBurden }_{i}+\gamma_{8} \text { numYears }{ }_{t}+\gamma_{9} \text { numYear } s_{t} \times \text { relativeBurden }_{i}}_{\text {Direct Effect }} \\
& \frac{\partial \ln \left(\text { newCases }_{i t}\right)}{\partial r_{i t}}=\underbrace{\beta_{1} \frac{\partial \text { duration }_{i t}}{\partial r_{i t}}}_{\text {Indirect Effect }} \\
& +\underbrace{\beta_{2}+\beta_{3} \text { relativeBurden }_{i}+\beta_{8} \text { numYears } s_{t}+\beta_{9} \text { numYears } s_{t} \times \text { relativeBurden }_{i}}
\end{aligned}
$$

Which yields:

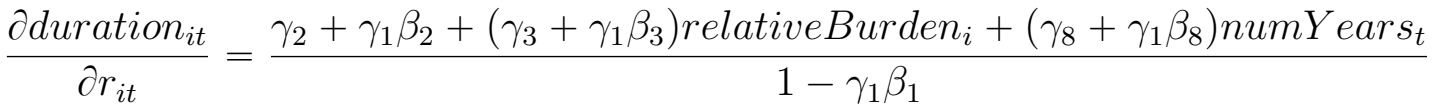

$$
\begin{aligned}
& +\frac{\left(\gamma_{9}+\gamma_{1} \beta_{9}\right) \text { numYears }_{t} \times \text { relativeBurden }_{i}}{1-\gamma_{1} \beta_{1}}
\end{aligned}
$$

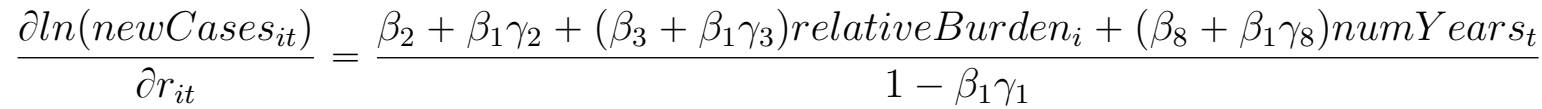

$$
\begin{aligned}
& +\frac{\left(\beta_{9}+\beta_{1} \gamma_{9}\right) \text { numYears } s_{t} \times \text { relativeBurden }}{1-\beta_{1} \gamma_{1}}
\end{aligned}
$$

Spatial Specification The spatial specification is defined by the following system of equations:

$$
\begin{aligned}
& \text { duration }_{i t}= \gamma_{0}+\gamma_{1} \ln \left(\text { newCase }_{i t}\right)+\gamma_{2} r_{i t}+\gamma_{3} r_{i t} \times \text { relativeBurden }_{i}+\gamma_{4} \text { departage }_{i t} \\
&+\gamma_{5} \ln (\text { gdp })_{i t}+\gamma_{6} \text { unemployment }_{i t}+\gamma_{7} \ln (\text { pop })_{i t}+\gamma_{8} r_{i t} \times \text { distance }_{i} \\
&+\gamma_{9} r_{i t} \times \text { distance }_{i} \times \text { relativeBurden } \\
&
\end{aligned}
$$

$$
\begin{aligned}
& \ln \left(\text { newCases }_{i t}\right)= \beta_{0}+\beta_{1} \text { duration }_{i t}+\beta_{2} r_{i t}+\beta_{3} r_{i t} \times \text { relativeBurden }_{i}+\beta_{4} \text { winRate }_{i t} \\
&+\beta_{5} \ln (\text { gdp })_{i t}+\beta_{6} \text { unemployment }_{i t}+\beta_{7} \ln (\text { pop })_{i t}+\beta_{8} r_{i t} \times \text { distance }_{i} \\
&+\beta_{9} r_{i t} \times \text { distance }_{i} \times \text { relativeBurden } \\
& i
\end{aligned}
$$

Note that these two equations do not include controls for distance nor relativeBurden $\times$ distance because they would be collinear with the court fixed effects.

The marginal effects of the reform are given by: 


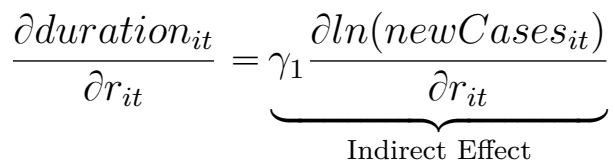

$$
\begin{aligned}
& +\underbrace{\gamma_{2}+\gamma_{3} \text { relativeBurden }_{i}+\gamma_{8} \text { distance }_{i}+\gamma_{9} \text { distance }_{i} \times \text { relativeBurden }_{i}} \\
& \frac{\partial \ln \left(\text { newCases }_{i t}\right)}{\partial r_{i t}}=\underbrace{\beta_{1} \frac{\partial \text { duration }_{i t}}{\partial r_{i t}}}_{\text {Indirect Effect }} \\
& \text { Direct Effect } \\
& +\underbrace{\beta_{2}+\beta_{3} \text { relativeBurden }_{i}+\beta_{8} \text { distance }_{i}+\beta_{9} \text { distance }_{i} \times \text { relativeBurden }_{i}} \\
& \text { Direct Effect }
\end{aligned}
$$

Which yields:

$$
\begin{aligned}
\frac{\text { duration }_{i t}}{\partial r_{i t}} & =\frac{\gamma_{2}+\gamma_{1} \beta_{2}+\left(\gamma_{3}+\gamma_{1} \beta_{3}\right) \text { relativeBurden }_{i}+\left(\gamma_{8}+\gamma_{1} \beta_{8}\right) \text { distance }_{i}}{1-\gamma_{1} \beta_{1}} \\
& +\frac{\left(\gamma_{10}+\gamma_{1} \beta_{9}\right) \text { distance }_{i} \times \text { relativeBurden }_{i}}{1-\gamma_{1} \beta_{1}} \\
\frac{\partial \ln \left(\text { newCases }_{i t}\right)}{\partial r_{i t}} & =\frac{\beta_{2}+\beta_{1} \gamma_{2}+\left(\beta_{3}+\beta_{1} \gamma_{3}\right) \text { relativeBurden }_{i}+\left(\beta_{8}+\beta_{1} \gamma_{8}\right) \text { distance }_{i}}{1-\beta_{1} \gamma_{1}} \\
& +\frac{\left(\beta_{10}+\beta_{1} \gamma_{9}\right) \text { distance }_{i} \times \text { relativeBurden }_{i}}{1-\beta_{1} \gamma_{1}}
\end{aligned}
$$




\section{Appendix 4: Marginal Effects at the National Level}

In order to compute the national average effect of the reform, we attribute a weight $w_{i}$ to each court. Let us denote $z_{j}$ the average number of claims between 2004 and 2007 the removed court $j$ was dealing with. For each receiving court $i$, we denote $J(i)$ the set of removed courts the receiving court $i$ is taking on. Each weight is defined as:

$$
w_{i}=\frac{\sum_{j \in J(i)} z_{j}}{\sum_{k} z_{k}}
$$

It follows that $\sum_{i} w_{i}=1$.

General Specification Let us denote $f$ (relativeBurden) the marginal impact of the reform conditionally on relativeBurden. In the general 3SLS specification, the average national effect of the reform on the dependent variable is linear in relativeBurden (see previous section in the appendix). The national average marginal impact corresponds to $\sum_{i} w_{i} f\left(\right.$ relativeBurden $\left._{i}\right)$.

Moreover, because of the linearity of $\mathrm{f}($.$) , we have:$

$$
\begin{aligned}
\sum_{i} w_{i} f\left(\text { relativeBurden }_{i}\right) & =\sum_{i} w_{i}\left(a \times \text { relativeBurden }_{i}+b\right) \\
& =a \times\left(\sum_{i} w_{i} \times \text { relativeBurden } i\right)+\sum_{i} w_{i} b \\
& =a \times\left(\sum_{i} w_{i} \times \text { relativeBurden }{ }_{i}\right)+b \\
& =f\left(\sum_{i} w_{i} \times \text { relativeBurden }_{i}\right)
\end{aligned}
$$

It follows that, because of the linearity of the marginal effect, the average marginal effect is equal to the marginal effect at the average. We can therefore compute the national average effect by considering the marginal effect at the national average.

Spatial Specification Let us denote $g$ (relativeBurden, distance) the marginal impact of the reform conditionally on both the relativeBurden and the distance of a court. The previous section has shown that the marginal effect is a function of the form: $g(x, y)=a x+b y+c x y+d$. The national average marginal impact is defined by $\sum_{i} w_{i} g\left(\right.$ relativeBurden $_{i}$, distance $\left._{i}\right)=\sum_{i} g_{i}$. Unlike in the general setting, the marginal impact is not linear anymore. The national marginal impact is given by:

$$
\begin{aligned}
& \sum_{i} w_{i} g_{i}=\sum_{i} w_{i}\left[a \times \text { relativeBurden } n_{i}+b \times \text { distance }_{i}+c \times \text { relativeBurden }_{i} \times \text { distance }_{i}+c\right] \\
& =a\left(\sum_{i} w_{i} \times \text { relativeBurden }{ }_{i}\right)+b\left(\sum_{i} w_{i} \times \text { distance }_{i}\right) \\
& +c\left(\sum_{i} w_{i} \times \text { relativeBurden }{ }_{i} \times \text { distance }_{i}\right)+c
\end{aligned}
$$

The data yield the following results: 


$$
\begin{aligned}
\sum_{i} w_{i} \times \text { relativeBurden }_{i} & =22.33678 \\
\sum_{i} w_{i} \times \text { distance }_{i} & =38.71412 \\
\sum_{i} w_{i} \times \text { relativeBurden }_{i} \times \text { distance }_{i} & =857.2087
\end{aligned}
$$

Time Specification The time specification conditions the impact of the reform on both the relative burden of the receiving courts and the number of years the reform has been enforced. Since each graph of figures 6 and 7 is already conditioned on the year, the marginal effect is linear, and results are similar to the general specification. We can take the marginal effect at the national average to estimate the national average marginal effect. 


\section{E Appendix 5: Graphs of marginal effects}
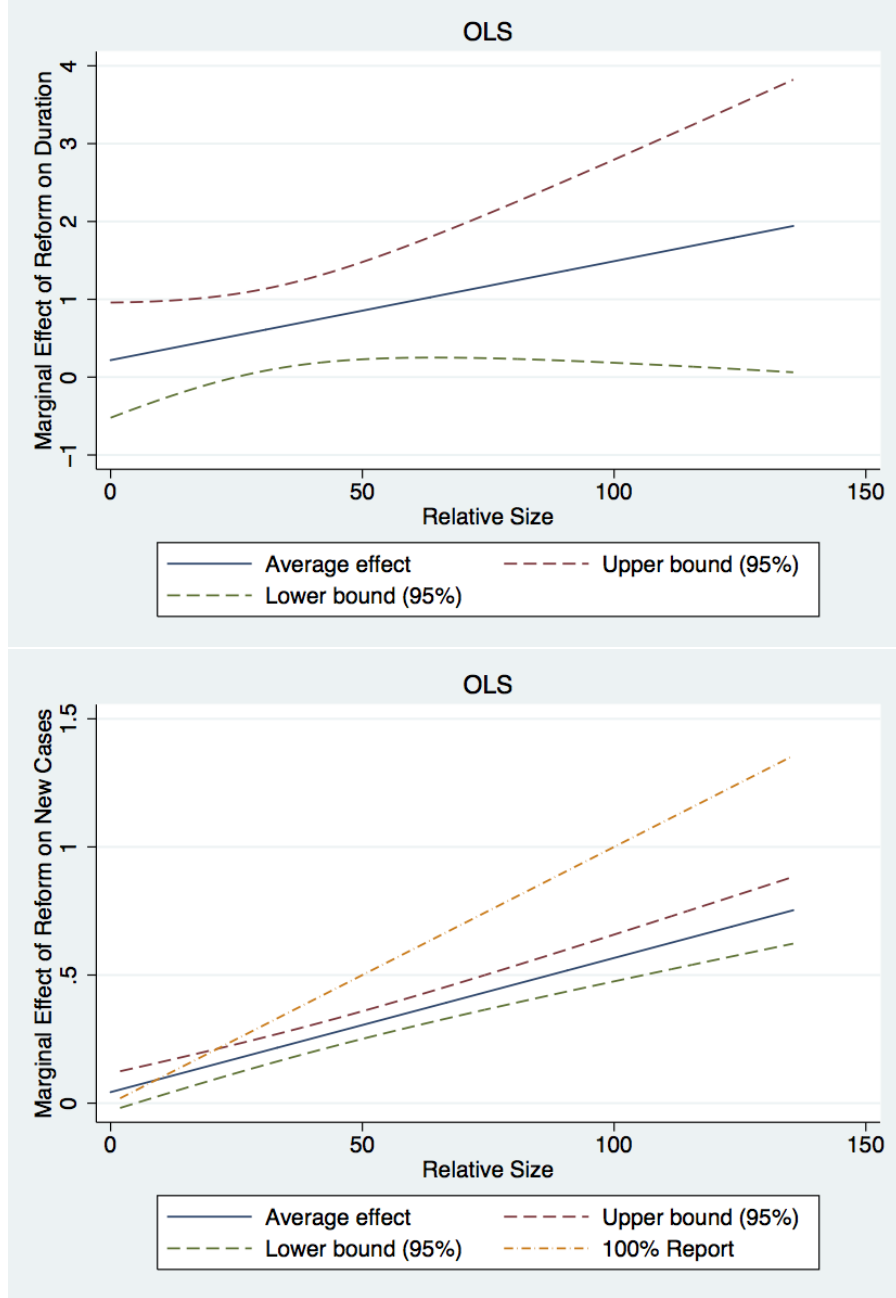

Figure 5: Marginal effect of the reform with OLS estimations. 

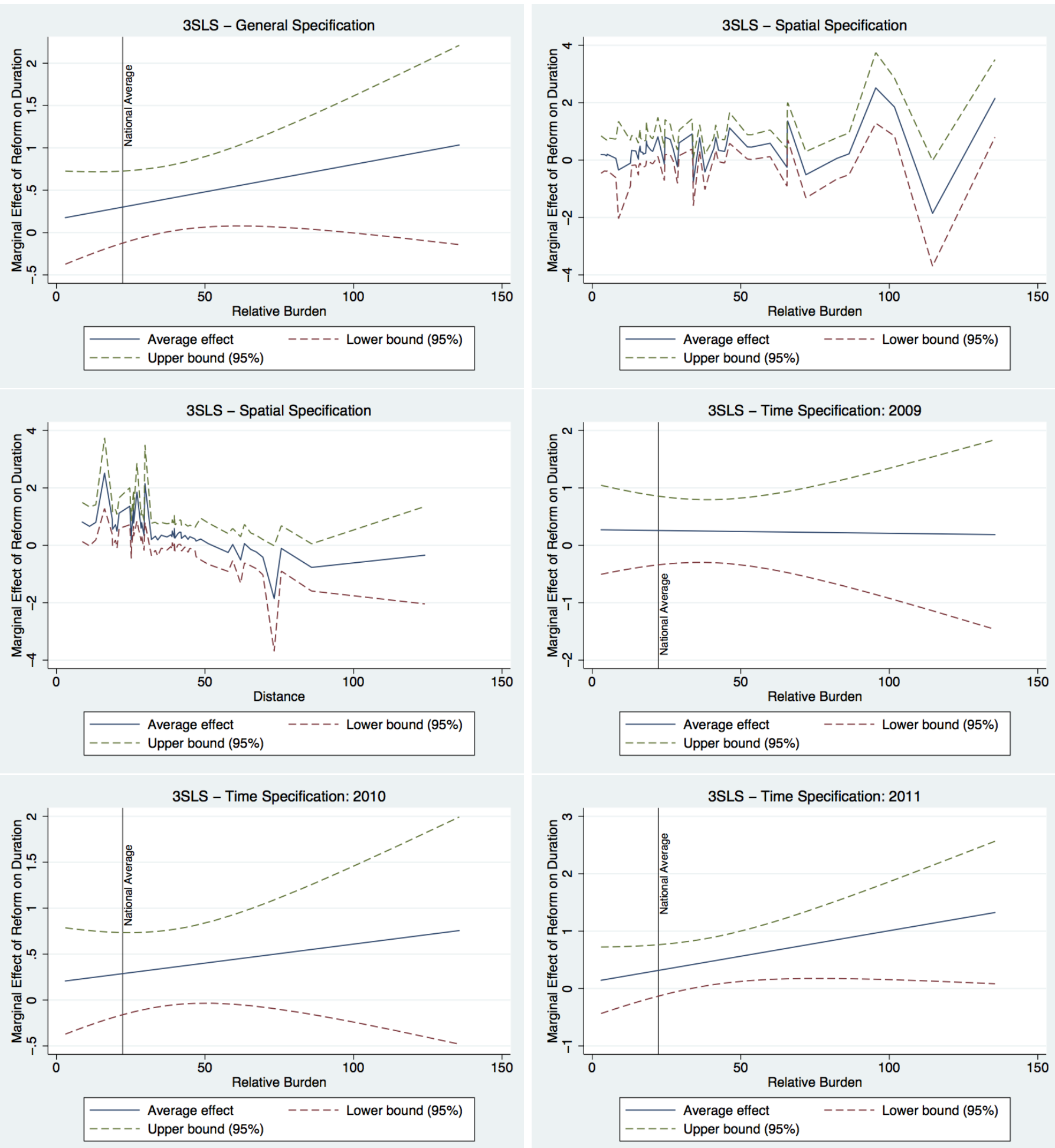

3SLS - Time Specification: 2012

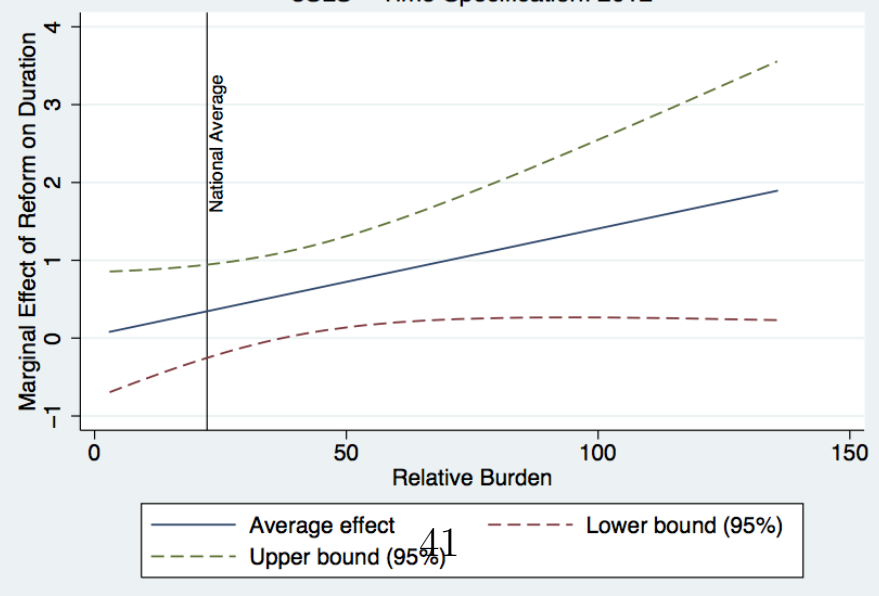



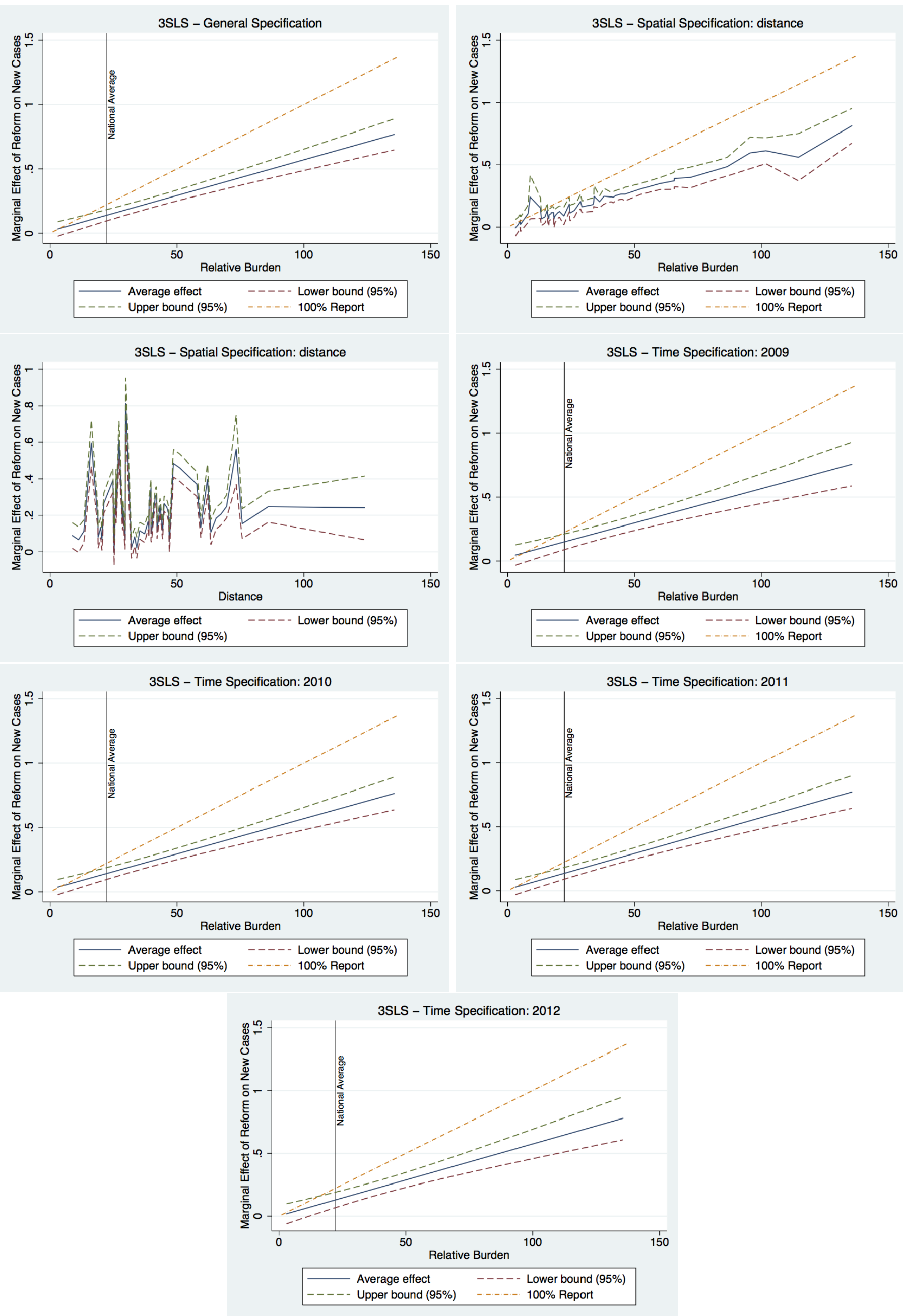